\title{
Interannual variability in hindcasts of atmospheric chemistry: the role of meteorology
}

\author{
P. Hess ${ }^{1,3}$ and N. Mahowald ${ }^{2,3}$ \\ ${ }^{1}$ Department of Biological and Environmental Engineering, Cornell University, Ithaca NY, USA \\ ${ }^{2}$ Department of Earth and Atmospheric Sciences, Cornell University, Ithaca NY, USA \\ ${ }^{3}$ National Center for Atmospheric Research, Boulder, CO, USA
}

Received: 31 October 2008 - Published in Atmos. Chem. Phys. Discuss.: 3 February 2009

Revised: 25 May 2009 - Accepted: 5 July 2009 - Published: 29 July 2009

\begin{abstract}
Two 40-year meteorological datasets are used to drive the Model of Ozone and Related Tracers chemical transport model, version 2 (MOZART2) in hindcast simulations. One dataset is from the National Center for Environmental Prediction/National Center for Atmospheric Research (NCEP/NCAR) reanalysis, the second dataset uses meteorology from the Community Atmosphere Model (CAM3) forced with observed interannually varying sea surface temperatures. All emissions, except those from lightning are annually constant. Analysis of these simulations focuses on the period between 1979-1999, due to meteorological discontinuities in the NCEP reanalysis during the 1970s. The meteorology using CAM3 captures observed trends in temperature and water vapor; the simulation using NCEP meteorology does not. This paper examines the regional and global interannual variability of various chemical and meteorological fields: $\mathrm{CO}, \mathrm{OH}, \mathrm{O}_{3}$ and $\mathrm{HNO}_{3}$, the surface photolysis rate of $\mathrm{NO}_{2}$ (as a proxy for overhead cloudiness), lightning $\mathrm{NO}$ emissions, water vapor, planetary boundary layer height, and temperature. The variability due to changes in emissions is not considered in this analysis. In both the NCEP and CAM3 simulations the relative variability of $\mathrm{CO}, \mathrm{OH}, \mathrm{O}_{3}$ and $\mathrm{HNO}_{3}$ are qualitatively similar, with variability maxima both in the tropics and the high latitudes. Locally, relative variability generally ranges between 3 and 10\%; globally the tropospheric variability generally ranges from half to one percent, but can be higher. For most fields the leading global Empirical Orthogonal Function explains approximately $10 \%$ of the variability and correlates significantly with El Niño. In both simulations the first principal component of a multiple tracer, globally averaged analysis shows a strong coupling between
\end{abstract}

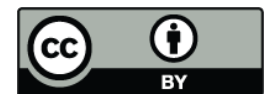

Correspondence to: P. Hess (pgh25@cornell.edu) surface temperature, measures of the hydrological cycle, $\mathrm{CO}$ and $\mathrm{OH}$, but is not correlated with El Niño. In both simulations we examine the global response of the selected variables to changes in global surface temperature, and compare with a climate simulation over the 21 st century.

\section{Introduction}

Projections of future climate change and air quality rely on predicted changes in atmospheric composition. How confident can we be in these predictions? This question can be partially addressed by using predictive models in hindcast experiments: a failure to simulate historical changes in chemical composition suggests a low confidence in predictions of future change. An accurate chemical hindcast will simulate the chemical response to interannual changes in the meteorology and emissions superimposed on a changing climate. As a first step this paper analyzes hindcasts of the chemical variability solely due to changes in meteorology and climate.

Significant interannual variations have been observed or inferred for many tropospheric species including ozone (e.g., Prather and et al., 2001), methane (e.g., Bousquet et al., 2006), OH (e.g., Bousquet et al., 2005), carbon monoxide (e.g., Edwards et al., 2004) and nitrous oxide (e.g., Nevison et al., 2007). There is little doubt that variability in emissions plays an important role in the observed chemical variability. However, assuming all variability can be ascribed to changes in emissions leads to false conclusions: much of the equatorial ozone change during the 1997-1998 El Niño can be explained by meteorological effects despite the dramatic increase in Indonesian fires during the El Niño year of 1997 (Sudo and Takahashi, 2001); a significant fraction of the variability of ozone in the Northern Hemisphere can be

Published by Copernicus Publications on behalf of the European Geosciences Union. 
explained by the Arctic Oscillation (AO) (Hess and Lamarque, 2007; Lamarque and Hess, 2004); the interannual differences in carbon monoxide measured at several Atlantic Ocean stations between 1991 and 1993 is largely explained by changes in transport (Allen et al., 1996); meteorological change has also been shown to be an important driver of interannual fluctuations of surface methane (Warwick et al., 2002; Chen and Prinn, 2005).

Besides the variability in meteorological fields and emissions, the impact of climate trends should not be neglected in hindcasts of chemical variables. The long-term trend in global temperature and water vapor over the last 40 years is comparable or larger than the detrended interannual variability in these fields; globally averaged temperature has increased by approximately $0.6^{\circ} \mathrm{K}$ since 1960 , and precipitable water vapor has increased by approximately $0.4 \mathrm{~mm}$ per decade between 1988 and 2003 (Trenberth et al., 2005). The effect of these long-term trends on constituent fields has not been quantified, but may be important.

Hindcast simulations of atmospheric composition require long-term meteorological datasets. Meteorological reanalysis products (e.g., the National Center for Environmental Prediction/National Center for Atmospheric Research (NCEP/NCAR) reanalysis) based on meteorological observations are an obvious choice (Kalnay et al., 1996). However, as reanalysis products are not available for future projections, it is also sensible to base hindcasts on the meteorology generated from a general circulation model (GCM). Both these options, however, are encumbered by a number of problems which act to limit their usefulness.

Constituent variability and transport driven by GCM winds is affected by model bias (for a discussion of biases in the Community Climate System Model version 3 (CCM3) see Collins et al., 2006). In addition, GCM winds cannot reproduce the episodic meteorology as observed during a specific field campaign. However, GCMs capture many observed large-scale meteorological changes when driven with observed sea-surface temperatures (SSTs) and are crucial in predicting future changes.

Reanalysis datasets generally capture the episodic meteorology observed during a particular field campaign but suffer from temporal changes in the observational network. This is particularly the case with the advent of satellite observations in the 1970s. Prior to the establishment of the global observing system in 1979, observational records have considerable deficiencies (Bengtsson et al., 2004). The advent of satellite observations marks a discontinuity in the meteorological dataset. However, even after 1979 major problems have been noted in the means, variability and trends in the NCEP/NCAR reanalysis as well as in the European Centre for Medium Range Weather Forecasts (ECMWF) 40 year reanalysis (ERA40) datasets (Trenberth et al., 2005). Bengtsson et al. (2004) concludes that climate trends cannot be reliably deduced from reanalysis data. The study by Mahowald et al. (2002) deduced that the reasons for the decadal changes in transport predicted by a model driven by analyzed winds were probably not robust, suggesting that a more systematic analysis is necessary. On the other hand Bowman and Erukhimova (2004) show that the transport characteristics in the NCEP reanalysis are generally similar to those in the NCAR Community Climate Model, but with noticeable differences in the tropics.

There is an additional role hindcast experiments can fulfill. On regional scales the planning and interpretation of chemical field campaigns necessitates an appreciation of the interannual variability of the measured constituents, yet this variability is poorly known in most locations. The set of experiments described below will help to quantify the expected impact of meteorological variability on atmospheric constituents.

In this paper we report on the interannual variability in two idealized hindcast chemical simulations, one run with meteorology from a General Circulation Model, the Community Atmosphere Model version 3 (CAM3) (Collins et al., 2006) constrained using observed SSTs, the other using meteorology from the NCEP/NCAR reanalysis (Kistler et al., 2001). This paper examines some of the drawbacks and advantages of these two types of meteorological datasets. There are other meteorological analyses we could equally well have chosen including reanalysis from the ECMWF (Uppala et al., 2005) or the reanalysis from the Data Assimilation Office (DAO) of the Goddard Laboratory for Atmospheres. Our results do not automatically apply to the other meteorological analysis products.

The emissions are kept annually constant in these simulations in order to isolate the role of meteorology. We do not include aerosols in these simulations; while the variability of aerosols is certainly important, as are the interactions between chemistry, aerosols and climate, we have chosen to simplify the problem by restricting ourselves to gas-phase chemistry. We examine the variability on the regional and global scales, determine the extent to which climate trends affect the variability and analyze the sensitivity of the variability to the input meteorological dataset. The paper is organized as follows. Section 2 describes the simulations and Sect. 3 gives the analysis techniques. We present regional patterns of spatial variability in Sect. 4 and the large scale variability in Sect. 5. The role of climate induced variability is given in Sect. 6. The paper concludes with conclusions and discussion in Sect. 7.

\section{Simulations}

In the simulations described below two 40-year meteorological datasets are used to drive the Model of Ozone and Related Tracers chemical transport model, version 2 (MOZART2) in hindcast simulations. For reasons described below these simulations are analyzed in detail only after 1979. One meteorological dataset is from the NCEP/NCAR reanalysis 
Table 1. Correlation $(R)$ of the 1st EOF for each field with El Niño, with NAO and with time and the variance explained by the 1st EOF. If the 2nd EOF correlates better with El Niño then its correlation and variance explained is given in parenthesis. Only values statistically significant at the $95 \%$ are shown in the table. Values statistically significant at the $99 \%$ are shown in bold face. There are 252 samples for El Niño and time correlations, and 21 for the NAO correlation.

\begin{tabular}{|c|c|c|c|c|c|c|c|c|}
\hline \multirow[b]{2}{*}{ Field } & \multicolumn{4}{|c|}{ CAMC } & \multicolumn{4}{|c|}{ NCEPC } \\
\hline & $\begin{array}{l}R \text { with } \\
\text { El Niño }\end{array}$ & $\begin{array}{l}R \text { with } \\
\text { NAO }\end{array}$ & $\begin{array}{l}R \text { with } \\
\text { time }\end{array}$ & $\begin{array}{c}\text { Variance } \\
\text { explained }(\%)\end{array}$ & $\begin{array}{l}R \text { with } \\
\text { El Niño }\end{array}$ & $\begin{array}{l}R \text { with } \\
\text { NAO }\end{array}$ & $\begin{array}{l}R \text { with } \\
\text { time }\end{array}$ & $\begin{array}{c}\text { Variance } \\
\text { explained }(\%)\end{array}$ \\
\hline $\mathrm{O}_{3}$ & $\begin{array}{c}0.34 \\
(0.70)\end{array}$ & NS & $\begin{array}{l}\text { NS } \\
(\mathrm{NS})\end{array}$ & $\begin{array}{c}5.6 \\
(5.3)\end{array}$ & -0.75 & NS & NS & 6.6 \\
\hline $\mathrm{CO}$ & -0.32 & NS & NS & 10.9 & $\begin{array}{c}0.18 \\
(-0.46)\end{array}$ & NS & $\begin{array}{c}-0.39 \\
(-0.11)\end{array}$ & $\begin{array}{l}10.1 \\
(7.0)\end{array}$ \\
\hline $\mathrm{OH}$ & $\begin{array}{l}-0.44 \\
(0.46)\end{array}$ & NS & $\begin{array}{c}-0.16 \\
(\mathrm{NS})\end{array}$ & $\begin{array}{c}6.2 \\
(4.1)\end{array}$ & $\begin{array}{l}-0.50 \\
(0.69)\end{array}$ & NS & $\begin{array}{c}-0.22 \\
(-0.35)\end{array}$ & $\begin{array}{c}8.1 \\
(5.1)\end{array}$ \\
\hline $\mathrm{HNO}_{3}$ & 0.18 & NS & NS & 5.3 & 0.12 & 0.69 & NS & 6.6 \\
\hline $\mathrm{JNO}_{2}^{\mathrm{a}}$ & 0.84 & NS & NS & 2.3 & 0.49 & NS & 0.25 & 5.3 \\
\hline $\mathrm{LNO}^{\mathrm{b}}$ & -0.50 & NS & NS & 5.1 & NS & NS & 0.32 & 11.1 \\
\hline $\mathrm{PBLH}^{\mathrm{c}}$ & -0.79 & NS & NS & 3.8 & -0.71 & NS & -0.16 & 3.8 \\
\hline PRECT $^{\mathrm{d}}$ & NS & NS & 0.13 & 7.1 & 0.85 & NS & NS & 7.7 \\
\hline $\mathrm{Q}^{\mathrm{e}}$ & 0.82 & NS & NS & 8.0 & 0.87 & NS & -0.19 & 8.54 \\
\hline
\end{tabular}

${ }^{a}$ Photolysis rate of $\mathrm{NO}_{2}$ at the surface; ${ }^{\mathrm{b}}$ Total source of lightning $\mathrm{NO}_{\mathrm{x}} ;{ }^{\mathrm{c}}$ Planetary Boundary Layer Height; ${ }^{\mathrm{d}}$ Total Precipitation; ${ }^{\mathrm{e}}$ Water Vapor

dataset. Meteorological fields for the second simulation are generated using CAM3 forced with observed interannually varying SSTs. Constraining GCMS with fixed SSTs tightly constrains certain aspects of the simulations, in particular changes in water vapor (Soden, 2000). The emissions and chemical mechanisms are identical in the two simulations.

The input meteorology affects the concentration of chemical constituents through transport, washout and chemical reaction rates. The latter depends on the input temperature, water vapor and clouds (impacting photolysis rates). In each meteorological dataset the input meteorological fields are spectrally truncated to T42 (Triangular 42) and interpolated onto the MOZART-2 grid, approximately $2.8^{\circ}$ in longitude and latitude. Each meteorological dataset has 26 vertical levels, although the vertical levels differ somewhat between the datasets. Differences in the vertical levels may have subtle impacts on the simulations, including the simulation of convection, lightning $\mathrm{NO}_{\mathrm{x}}$ emissions and boundary layer transport. MOZART-2 rediagnoses the convective mass fluxes, the subgrid scale boundary layer transport and precipitation from the input meteorological fields (Mahowald et al., 1997; Rasch et al., 1997). Dry convection and boundary layer mixing is represented using the parameterization of Holtslag and Boville (1993). Moist convective transport is pararameterized using the Hack (1994) scheme for shallow and mid-level convection and a modified version of the Zhang and McFarlane (1995) scheme for deep moist convection. The moisture is prognostic in the model, except for the surface latent heat flux which is input from the driving meteorological fields.
MOZART-2 is described in detail in Horowitz et al. (2003). The source of $\mathrm{NO}_{\mathrm{x}}$ from lightning is parameterized following Price et al. (1997) and depends on the diagnosed convective cloud height and the cold cloud thickness. The vertical distribution of the $\mathrm{NO}_{\mathrm{x}}$ source follows a Cshape profile following Pickering et al. (1998). Stratospheric boundary conditions are specified for a number of species including ozone $\left(\mathrm{O}_{3}\right)$, nitric acid $\left(\mathrm{HNO}_{3}\right)$, carbon monoxide (CO) and methane $\left(\mathrm{CH}_{4}\right)$. In particular, ozone is relaxed in the stratosphere to climatological values. Photolysis rates are based on a look-up table and are affected by clouds through the parameterization of Chang (1987). The emissions used in these simulations are valid for 1997 and are from the Precursors of Ozone and their Effects in the Troposphere (POET) Project (Olivier et al., 1999). Isoprene and terpene emissions are prespecified and are taken from the Global Emissions Inventory Activity (Guenther et al., 1995). Methane is fixed at the lower boundary to prevent a long timescale chemical drift in the simulations. Washout is specified using a modified version of the Giorgi and Chameides scheme (Giorgi and Chameides, 1985) (for details see Horowitz et al., 2003). We do not specifically evaluate the model simulations here. First, this has been done in depth in previous work (Horowitz et al., 2003; Emmons et al., 2003; Tie et al., 2003); second, the goal of this paper is to compare and contrast the variability using two meteorological input datasets under a constant emission scenario, rendering a comparison with long term observational datasets difficult and outside the scope of this study. Actual emissions undergo substantial interannual variability with pronounced long-term trends. 


\section{Analysis}

A large number of output variables are archived during the course of the 40 year runs. Out of necessity we have been selective in the number of chemical and meteorological variables to analyze (see Table 1). The analyzed chemical constituents $\left(\mathrm{OH}, \mathrm{O}_{3}, \mathrm{HNO}_{3}\right.$, and $\left.\mathrm{CO}\right)$ have been broadly selected to be representative of changes in the chemical system. The hydroxyl radical $(\mathrm{OH})$ and $\mathrm{O}_{3}$ are central in determining tropospheric chemistry and composition. Ozone is also a regulated air pollutant and a radiatively important gas. $\mathrm{HNO}_{3}$ acts as a reservoir species for odd nitrogen and in addition is highly soluble. Thus it acts as a chemical marker of the sensitivity of wet deposition to changes in precipitation. $\mathrm{CO}$ is a tracer of combustion and acts as a generic marker for anthropogenic hydrocarbons.

The physical variables analyzed have been chosen for their affect on the chemical system. These variables include surface temperature, water vapor, planetary boundary layer height, the photolysis rate of nitrogen dioxide $\left(\mathrm{JNO}_{2}\right.$ : $\mathrm{NO}_{2} \rightarrow \mathrm{NO}$ ) at the surface, the production of nitrogen oxide (NO) emissions from lightning and precipitation. Surface temperature is important for diagnosing changes in climate, but also affects chemical reaction rates, and modifies atmospheric water vapor through the Clausius-Clapeyron equation. Water vapor plays a crucial role in tropospheric chemistry through its role in the loss of ozone and the production of $\mathrm{OH}$. The relative insensitivity of $\mathrm{JNO}_{2}$ to the overhead ozone column suggest that $\mathrm{JNO}_{2}$ is a sensitive indicator of total overhead cloudiness. Boundary layer height impacts the surface concentrations of emitted species and thus plays a key role in the chemistry of the troposphere. The production of NO by lightning is sensitive to convection and is an important source of upper tropospheric ozone (Labrador et al., 2004). Finally precipitation is important for the wash out of soluble species, as well as a sensitive indicator of shifts in circulation.

Empirical orthogonal functions (EOF) (also known as principal component analysis, PCA) are used to analyze both simulations: the simulation where NCEP meteorology drives the chemical simulation (NCEPC) and the simulation where CAM meteorology drives the chemical simulation (CAMC). This analysis gives orthogonal sets of intercorrelated variables obtained from the eigenvectors and eigenvalues of the correlation matrix. EOFs are used to separate the space and time variability of a variable into a number of orthogonal modes. The first EOF contains the dominant proportion of the variability, and each EOF thereafter contains less variability (Wilks, 2007).

\section{Regional variability}

We begin our analysis by showing the spatial structure of the constituent variability. In particular we show the relative

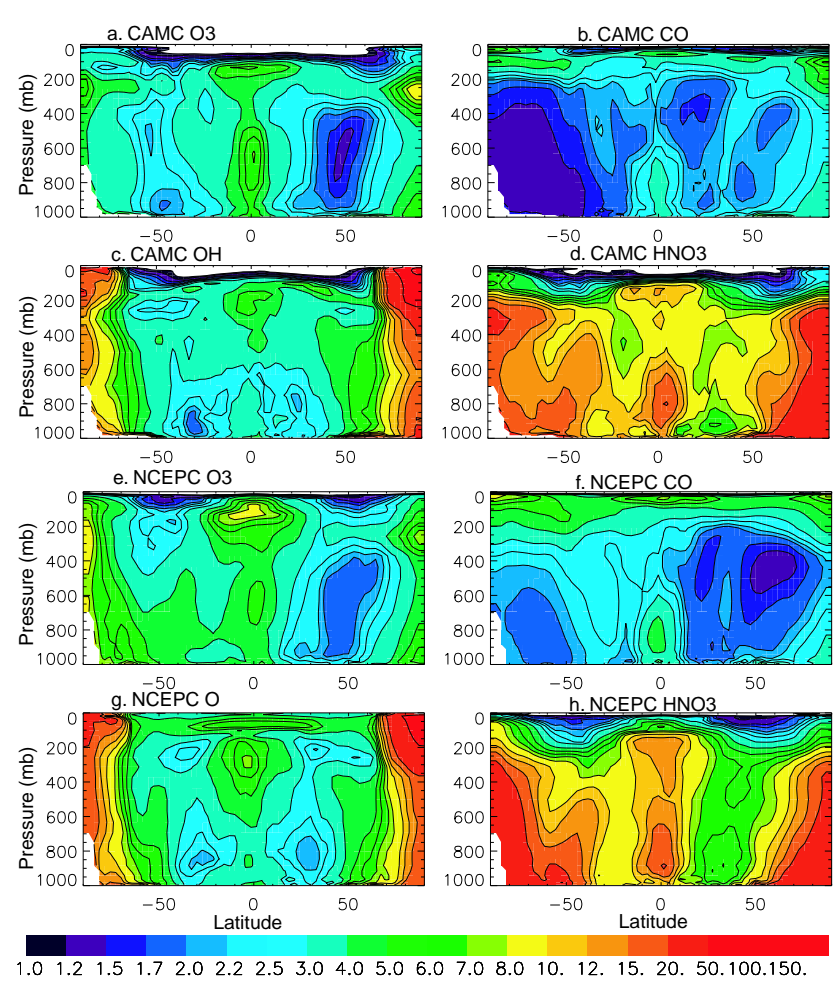

Fig. 1. Zonal mean of the relative variability defined as the standard deviation of the monthly anomalies (the monthly value minus the mean of all years for that month) divided by the mean for CAMC and NCEPC, respectively: (a) and (e) ozone; (b) and (f) CO; (c) and (g) $\mathrm{OH}$; (d) and (h) $\mathrm{HNO}_{3}$.

variability defined as the standard deviation of the monthly anomalies (the monthly value minus the mean of all years for that month) divided by the mean. EOF analysis is then used to examine the spatial structure of the variability and relate it to meteorological indexes of variability. We only analyze the simulations from 1979-1999 due to significant trends in the reanalysis prior to 1979 (see Sect. 5.1). Zhou and Sanso (2008) have applied statistical methods to determine if the two simulations are statistically the same.

\subsection{Zonal averages}

Cross sections of the relative interannual variability of $\mathrm{CO}$, $\mathrm{OH}, \mathrm{O}_{3}$ and $\mathrm{HNO}_{3}$ are shown in Fig. 1. Except for $\mathrm{OH}$ and $\mathrm{HNO}_{3}$ in the polar regions, the zonal average of the relative variability tends to range between a few and $10 \%$ for these species. The variability pattern is generally similar in CAMC and NCEPC although some notable differences do occur (e.g., ozone in the SH). The variability in the two simulations is of the same magnitude, although it tends to be somewhat larger in NCEPC.

The relative variability tends to be comparatively high in the tropics, with a local maximum in variability near the 

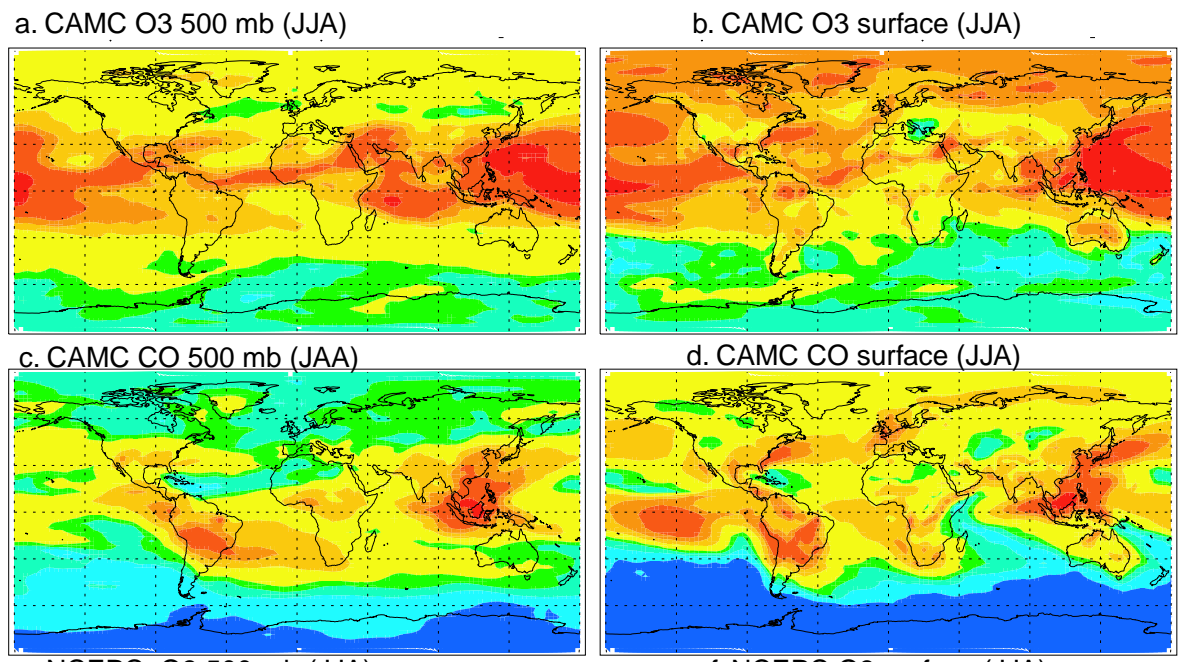

d. CAMC CO surface (JJA)
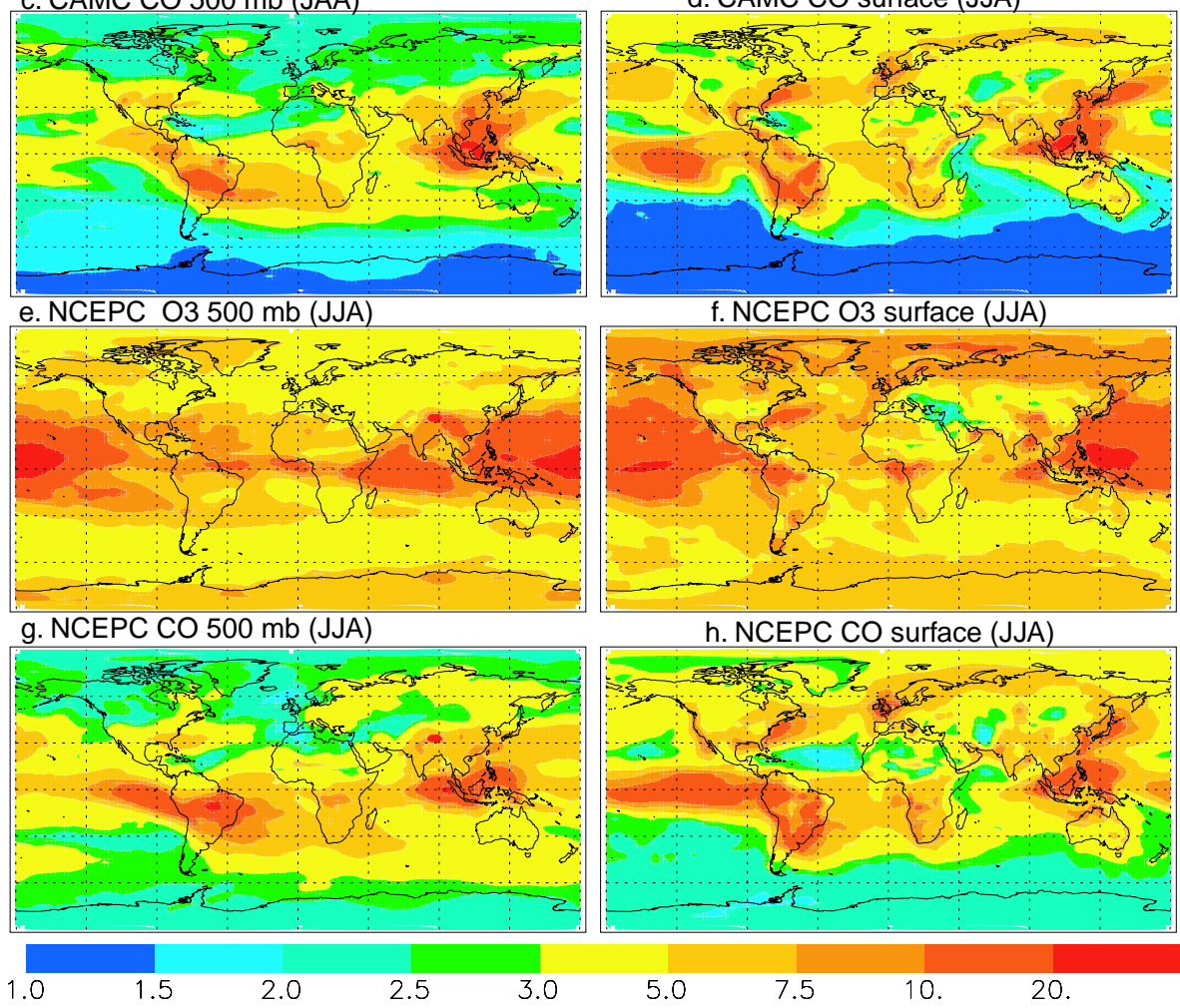

Fig. 2. Relative variability defined as the standard deviation of the monthly anomalies (the monthly value minus the mean of all years for that month) divided by the mean during JJA for CAMC and NCEPC, respectively: (a) and (e) ozone at $500 \mathrm{hPa}$; (b) and (f) ozone at the surface; (c) and (g) $\mathrm{CO}$ at $500 \mathrm{hPa}$; (d) and (h) $\mathrm{CO}$ at the surface.

equator in all fields and for both simulations. The high tropical variability may be due to a combination of several factors: 1) large meridional species gradients tend to occur in the tropics due to the predominance of $\mathrm{NH}$ emissions and the slow meridional mixing at the surface; 2) the variability of the meridional stream function has a pronounced maximum in the tropics (e.g., due to the location of the intertropical convergence zone) (Kallberg et al., 2005); 3) at low levels $(850 \mathrm{hPa}$ and lower) wind vectors tend to show maximum interannual variability near the equator (Kallberg et al., 2005). The local upper troposphere tropical maxima in $\mathrm{OH}$, $\mathrm{HNO}_{3}$ and $\mathrm{O}_{3}$ suggests high variability associated with convective outflow and may also be related to the variability in the meridional stream function or fluctuations in lightning $\mathrm{NO}_{\mathrm{x}}$.
The fields examined tend to have a variability minimum in midlatitude regions. The interannual variability of $\mathrm{CO}$ and $\mathrm{O}_{3}$ have a pronounced mid-latitude minimum near $50^{\circ}$ in both hemispheres. The upward and poleward orientation of this minimum suggests this feature involves the quasiisentropic transport by mid-latitude synoptic eddies. All fields also have comparatively high variability in the high latitudes of both hemispheres.

\subsection{Surface and mid-tropospheric interannual variabil- ity}

Figure 2 shows latitude-longitude sections of the interannual variability of $\mathrm{CO}$ and $\mathrm{O}_{3}$ during JJA in CAMC. We first concentrate on the $\mathrm{NH}$ summer months as this is the season when 
air pollution is usually at its worst. The variability in CAMC and NCEPC is generally similar. Locally relative variability maxima can reach $20 \%$, but variability between 3 and $10 \%$ is more common. As shown in Fig. 1, the variability maximizes near the equator for both $\mathrm{CO}$ and ozone in both simulations. However, Fig. 2 shows some interesting zonal asymmetries. First, for the most part the equatorial variability tends to be relatively small over the Atlantic basin, and to maximize within the Pacific and Indian Oceans. This may be linked to variability associated with El Niño Southern Oscillation (ENSO) or to interhemispheric transport variability which appears to maximize in the Pacific (e.g. Hartley and Black, 1995). Second, the maximum relative variability at the surface tends to occur over the oceans, perhaps due to low species surface concentrations over the ocean. Third, particularly in CAMC and NCEPC, high surface variability in mid-latitudes emanates from the major $\mathrm{NH}$ pollution regions across the Pacific and Atlantic oceans. Fourth, at $500 \mathrm{hPa}$ the $\mathrm{CO}$ variability maximum tends to be located over tropical emission regions. In contrast the highest ozone variability at $500 \mathrm{hPa}$ has a larger latitudinal range and predominantly occurs over the Pacific.

The variability of ozone over major emission regions is of interest in designing and monitoring effective air pollution strategies. While extreme events, such as the effect of the high ozone values during the 2003 European heat wave (Fischer et al., 2004) are notable, the results of these simulations suggest relatively modest interannual variation in ozone over the major emission regions. We find the relative standard deviation of ozone over the Eastern US is less than 10\% in CAMC and NCEPC; over Europe the interannual variability is also less than $10 \%$ in CAMC, but reaches values of $10-20 \%$ in NCEPC. Vukovich (1997) found an interannual standard deviation of maximum daily ozone of between approximately 5 and $10 \mathrm{ppbv}$ at 4 study sites over the Eastern half of the US during a 5 year study. Assuming 70 ppbv for the mean maximum daily ozone, this gives a relative variability in the range between 7 and 14\%, similar in range to our study. Andersson et al. (2007) found the interannual relative standard deviation of ozone over Europe between April and September ranges from less than $1 \%$ to a little greater than $5 \%$.

The interannual variability during DJF differs in detail from JJA, but is not qualitatively different (Fig. 3). The maximum ozone variability shifts from the NH during JJA to the SH during DJF, but the overall variability of CO does not exhibit a large-scale hemispheric shift. Pronounced regional differences in variability do occur between DJF and JJA. For example, over Indonesia, the variability of $\mathrm{CO}$ tends to be substantially larger during DJF than JJA both at the surface and at $500 \mathrm{hPa}$. Over Eastern North America, Europe and to some extent China the surface variability of $\mathrm{CO}$ and ozone during DJF maximizes over the land with oceanic minimum; during JJA the highest variability tends to occur over the oceans.

\subsection{Empirical orthogonal functions}

EOFs were generated for the period 1979-1999 for all analyzed fields. For multilevel fields we used data on four pressure levels for the EOF analysis: the surface, $850 \mathrm{hPa}$, $500 \mathrm{hPa}$ and $312 \mathrm{hPa}$. Fields are area weighted before the EOFs were calculated, but no altitudinal weighting was used. The variance explained by the leading EOF for any of the variables examined is approximately $10 \%$ or less (Table 1 ). Also given in Table 1 is the correlation of the EOFS with El Niño, NAO (North Atlantic Oscillation) and with year. If the 2nd EOF correlates better with El Niño than the first, its correlation and variance explained are given in parenthesis. We use SST anomalies from the Niño-3.4 region for our index of El Niño (Trenberth and Stepaniak, 2001), the NAO climate index is from Hurrell (1995) for the NCEP simulations, and the first EOF of North Atlantic surface pressures for the CAM simulation.

The North Atlantic Oscillation (or the related Arctic Oscillation) is a dominant mode of $\mathrm{NH}$ extratropical meteorological variability characterized by north-south fluctuations in atmospheric pressure within the Atlantic Basin. It has been shown to modify the variability of a number of chemical constituents (e.g., Hess and Lamarque, 2007; Lamarque and Hess, 2004; Eckhardt et al., 2003; Creilson et al., 2003; Creilson et al., 2005). However, the correlations between any of the EOFs and this mode of variability are generally not significant (except for $\mathrm{HNO}_{3}$ in NCEPC).

ENSO is a dominant mode of global meteorological variability and dominates the interannual variability of precipitable water (Trenberth et al., 2005). Trenberth et al. (2005) finds that both the precipitable water and the precipitable water variability in the NCEP reanalysis are biased low. CAMC generally has less precipitable water than NCEPC and comparable variability. See Hack et al. (2006) for a discussion of the hydrological cycle in CAM.

The highest correlations between the 1st (or 2nd) EOF and El Niño $(R>0.7)$ are found in both model simulations for ozone, water vapor, precipitable water and boundary layer height (Table 1). Both simulations also give significant correlations $(R>0.3)$ for $\mathrm{OH}, \mathrm{CO}$ and the photolysis rate of $\mathrm{NO}_{2}$. However, the simulations differ in their relationship between El Niño and total precipitation and lightning $\mathrm{NO}_{\mathrm{x}}$ emissions: NCEPC has a high correlation between El Niño and the 1st EOF of precipitation (in CAMC it is insignificant) while CAMC has a significant correlation between El Niño and the 1 st EOF of lightning $\mathrm{NO}_{\mathrm{x}}$ (in NCEPC it is insignificant).

Figure 4 shows the correlation in NCEPC and CAMC between ozone at $312 \mathrm{hPa}$ and the first EOF timeseries with a significant correlation with El Niño. Figure 4 shows a similar pattern to that reported by Peters et al. (2001) and Doherty et al. (2006). We obtain similar, albeit higher correlations when we use tropospheric column ozone for our EOF analysis (not shown). These results are also consistent with a number of 

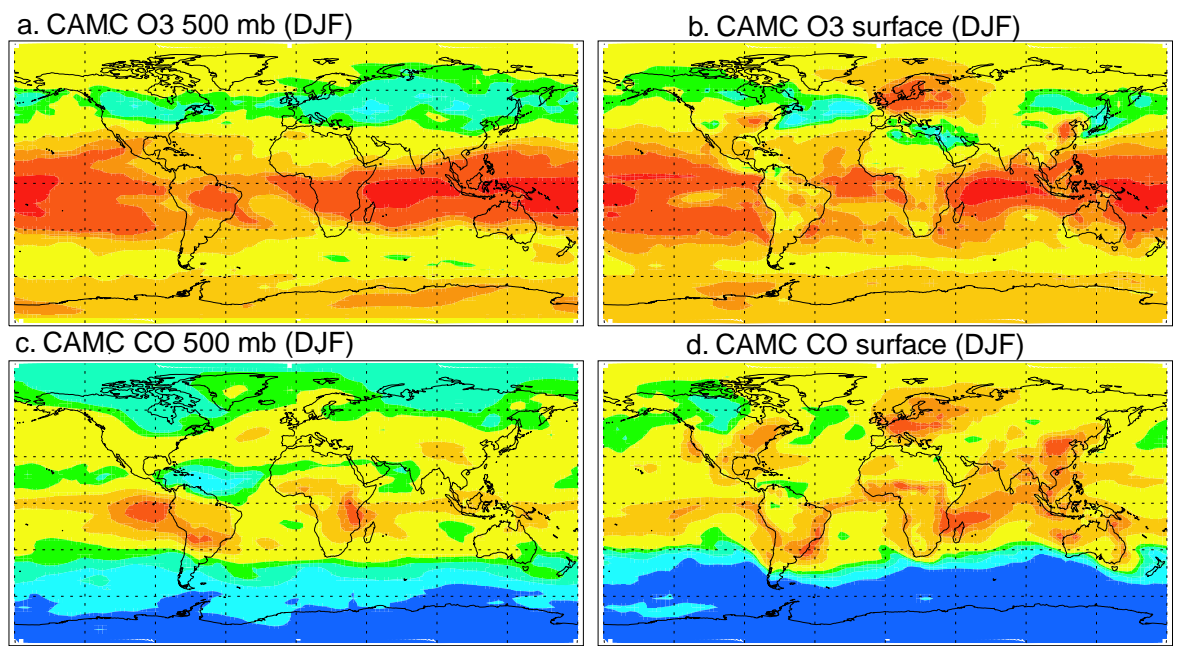

\section{d. CAMC CO surface (DJF)}
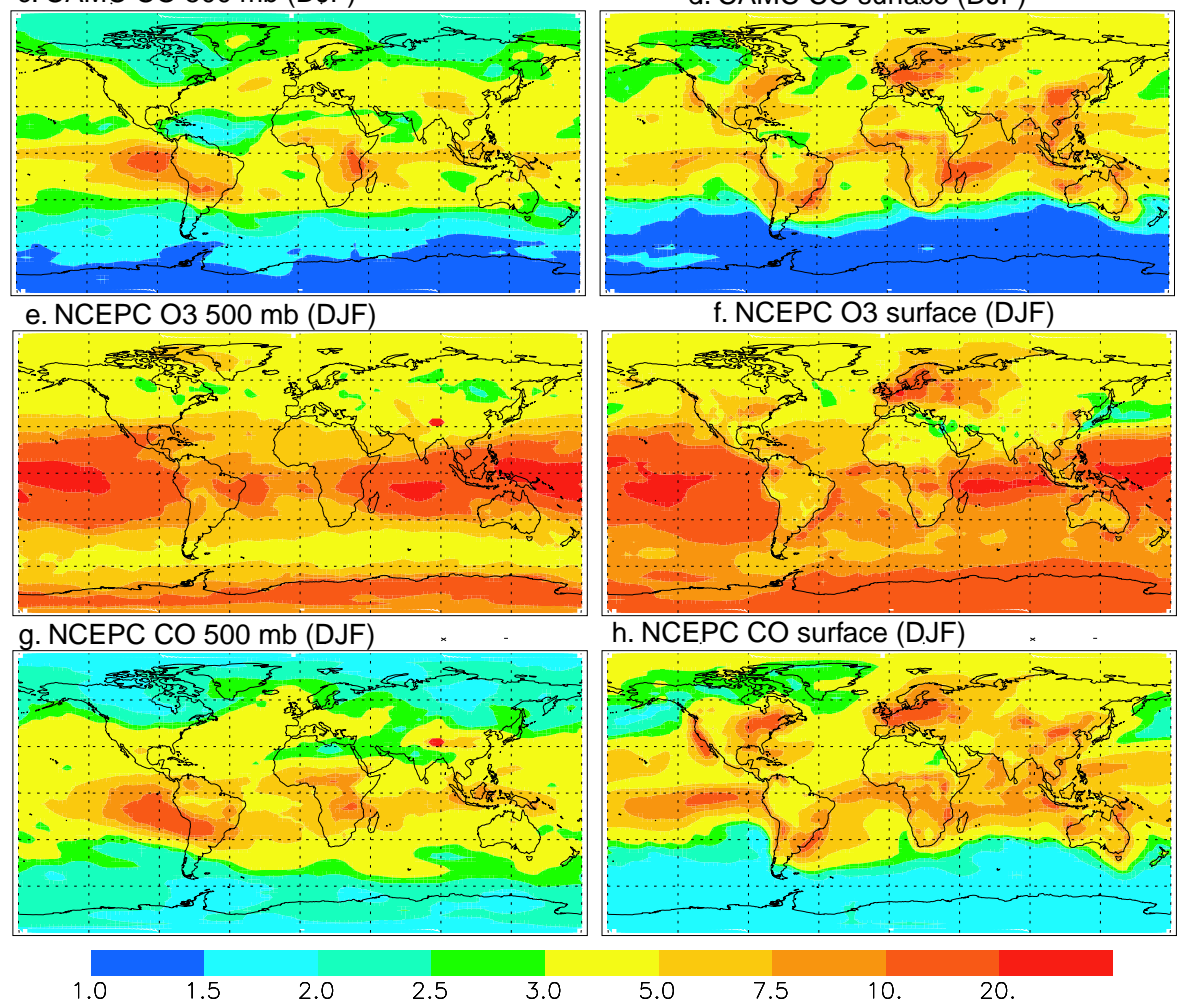

Fig. 3. Relative variability defined as the standard deviation of the monthly anomalies (the monthly value minus the mean of all years for that month) divided by the mean during DJF for CAMC and NCEPC, respectively: (a) and (e) ozone at $500 \mathrm{hPa}$; (b) and (f) ozone at the surface; (c) and (g) CO at $500 \mathrm{hPa}$; (d) and (h) $\mathrm{CO}$ at the surface.

\section{a. CAM EOF O3 (2nd)}

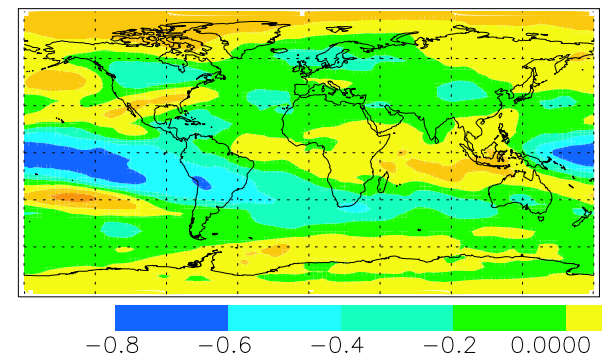

b. NCEP EOF O3 (1st)

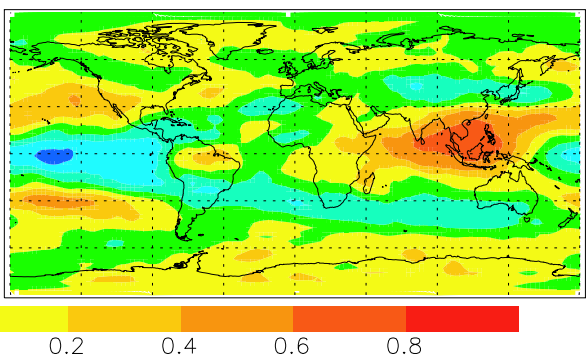

Fig. 4. Correlation of ozone with the ozone EOF most correlated with El Niño at $312.5 \mathrm{hPa}$ in (a) CAMC (the 2nd EOF) and (b) NCEPC (the 1st EOF). 
Table 2. Average, standard deviation (SD) and relative standard deviation (RSD; standard deviation divided by the mean) of globally averaged variables in CAMC and NCEPC. Three dimension variables are density weighted and averaged between the surface and $280 \mathrm{hPa}$. Three dimension quantities evaluated at the surface are prefixed with Sfc. The standard deviation is calculated as the standard deviation of the monthly anomalies (the monthly value minus the mean of all years for that month).

\begin{tabular}{lcccccc}
\hline & \multicolumn{5}{c}{ CAMC } & \multicolumn{5}{c}{ NCEPC } \\
\hline & Average & SD & RSD $(\%)$ & Average & SD & RSD (\%) \\
\hline $\mathrm{O}_{3}(\mathrm{ppbv})$ & 46 & 0.19 & 0.42 & 48.4 & 0.752 & 1.56 \\
$\mathrm{CO}(\mathrm{ppbv})$ & 83 & 0.45 & 0.54 & 85 & 0.39 & 0.46 \\
$\mathrm{OH}\left(\mathrm{mole} / \mathrm{mole} \times 10^{15}\right)$ & 73.5 & 0.71 & 0.96 & 70.4 & 0.85 & 1.2 \\
$\mathrm{HNO}_{3}(\mathrm{pptv})$ & 121 & 1.2 & 1.0 & 121 & 1.49 & 1.2 \\
$\mathrm{Sfc}_{3}(\mathrm{ppbv})$ & 29.8 & 0.12 & 0.41 & 31.2 & 0.47 & 1.5 \\
$\mathrm{Sfc}(\mathrm{C})$ & 287 & 0.12 & 0.040 & 287 & 0.12 & 0.042 \\
$\mathrm{Sfc} \mathrm{JNO}_{2}\left(\mathrm{~s}^{-1} \times 10^{-3}\right)$ & 2.43 & 0.0045 & 0.187 & 2.39 & 0.0081 & 0.341 \\
$\mathrm{LNO}^{\mathrm{a}}(\mathrm{TgN} / \mathrm{yr})$ & 4.71 & 0.12 & 2.5 & 2.79 & 0.21 & 7.6 \\
$\mathrm{PBLH}^{\mathrm{b}}(\mathrm{m})$ & 528 & 1.76 & 0.33 & 566 & 5.2 & 0.92 \\
$\mathrm{PRECT}^{\mathrm{c}}(\mathrm{mm} / \mathrm{day})$ & 2.42 & 0.015 & 0.6 & 2.4 & 0.039 & 1.6 \\
$\mathrm{Q}^{\mathrm{d}}(\mathrm{g} / \mathrm{kg})$ & 3.46 & 0.041 & 1.2 & 3.38 & 0.036 & 1.1 \\
\hline
\end{tabular}

${ }^{\mathrm{a}}$ Source of lightning odd nitrogen; ${ }^{\mathrm{b}}$ Planetary Boundary Layer Height; ${ }^{\mathrm{c}}$ Total Precipitation; ${ }^{\mathrm{d}}$ Water Vapor

observational studies showing a strong relationship between tropical ozone column and ENSO (e.g., Ziemke and Chandra, 2003; Ziemke and Chandra, 1999). The EOF correlations in NCEPC and CAMC differ most markedly in the western Pacific, where CAMC shows a much weaker signal over Indonesia.

Several of the EOFs show modest correlations with time, especially in the NCEPC simulation (Table 1). Correlations of various fields with time are examined in more detail in Sect. 5.4. We do not further explore the spatial distributions of the EOFs as they explain very little of the simulated variability.

\section{Large scale variability}

In this section we examine the interannual variability in the CAMC and NCEPC simulations on the large scale: either globally, or within the tropics. In this analysis the three dimensional variables have been density weighted and averaged between the surface and $280 \mathrm{hPa}$. On hemispheric and global scales the effect of interannual changes in meteorology on constituent variability is also not well known although a number of studies suggest it is important. Dentener et al. (2003) suggests that much of the interannual variability in $\mathrm{CH} 4$ and $\mathrm{OH}$ can be ascribed to large scale interannual changes in water vapor while Doherty et al. (2006) shows large scale global changes in tropospheric constituent burdens correlate with El Niño.

\subsection{Variability in global concentration burdens}

Timeseries of the selected globally averaged chemical and meteorological variables are given in Fig. 5 for the period 1960 to 2000. Significant changes are apparent in the timeseries of some variables between 1970 and 1980. This can likely be attributed to the incorporation of satellite data into the NCEP analysis during this period. The most apparent change is in the planetary boundary layer height, but obvious trends also occur in the $\mathrm{NO}_{2}$ photolysis rate (reflecting changes in cloud cover) and possibly surface ozone. Large trends are also evident in the timeseries of EOFs during this time period (not shown). It is for these reasons we have restricted our analysis to the period between 1979 and 1999 .

The average, standard deviation and relative standard deviation of the analyzed globally averaged variables are given in Table 2. The global average of the variables in CAMC and NCEPC are generally similar, with differences between the model simulations of less than 5\%. Exceptions are the planetary boundary layer height, and most notably the lightning $\mathrm{NO}_{\mathrm{x}}$ emissions, where the NCEPC global average is about half that in CAM. Except for surface temperature the relative standard deviation generally ranges between approximately one half percent to a maximum of almost $7.6 \%$ for lightning $\mathrm{NO}_{\mathrm{x}}$ emissions in NCEPC. The relative standard deviation of lightning $\mathrm{NO}_{\mathrm{x}}$ is about three times higher in NCEPC than in CAMC, although in both simulations this quantity has the highest relative standard deviation of any of the fields examined. Other fields with significantly different variability between the simulations include precipitation, planetary boundary layer height and ozone, all with greater 

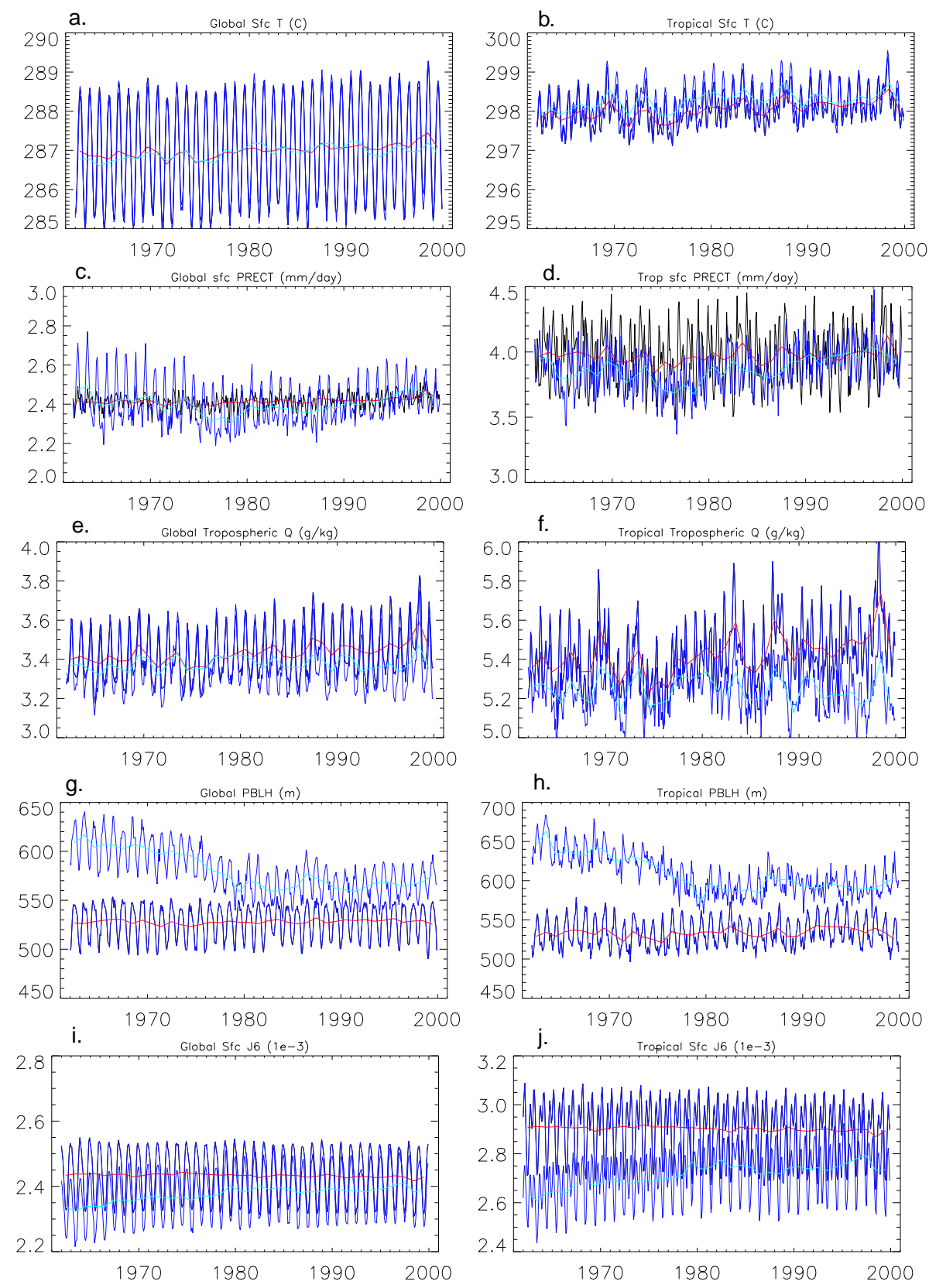

Fig. 5. Globally and Tropically $\left(20^{\circ} \mathrm{S}-20^{\circ} \mathrm{N}\right)$ averaged fields for the CAMC and NCEPC simulations. Three dimensional fields are area weighted and averaged over the troposphere using a density weighting, two dimensional fields are area weighted. Light blue is NCEPC with overlying blue giving the 12 month running average, dark blue is CAMC, with red giving the 12 month running average. Global and tropical fields, respectively for (a) and (b) temperature; (c) and (d) precipitation; (e) and (f) water Vapor, (g) and (h) planetary boundary layer height, (i) and (j) $\mathrm{NO}_{2}$ photolysis rate, (k) and (l) lightning $\mathrm{NO}_{\mathrm{x}}$ production; (m) and (n) $\mathrm{OH}$, (o) and (p) $\mathrm{O}_{3}$, (q) and (r) Surface $\mathrm{O}_{3}$.

variability in NCEPC. The relative standard deviation of precipitable water, $\mathrm{OH}$ and $\mathrm{HNO}_{3}$ is about $1 \%$ in both sets of simulations.

The relative global variability of $\mathrm{OH}$ in both simulations is significantly less than the variability of $\mathrm{OH}$ inferred from methyl chloroform measurements. The latter, which implic- itly accounts for the variability due to changes in emissions, is often estimated to be in the range of $10 \%$ (Bousquet et al., 2005; Prinn et al., 2005). However, Dentener et al. (2003) suggests interdecadal and interannual changes in $\mathrm{OH}$ must be significantly less than inferred from the methyl chloroform measurements as the large variability is difficult to reconcile 

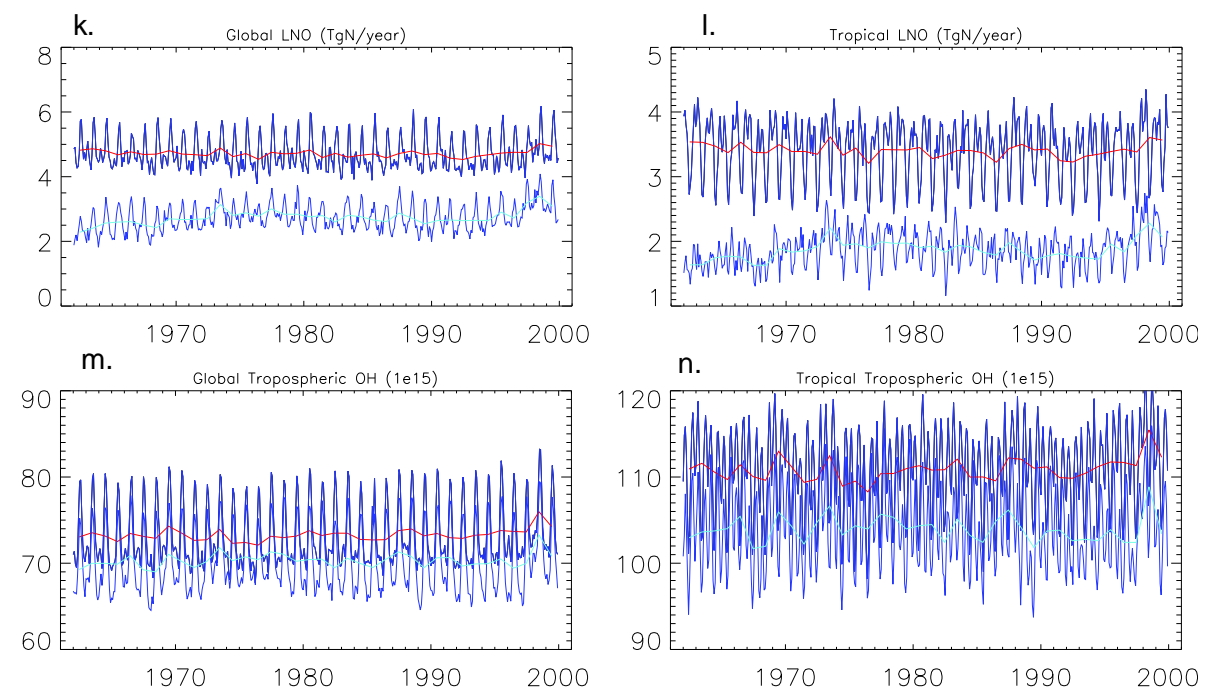

0.
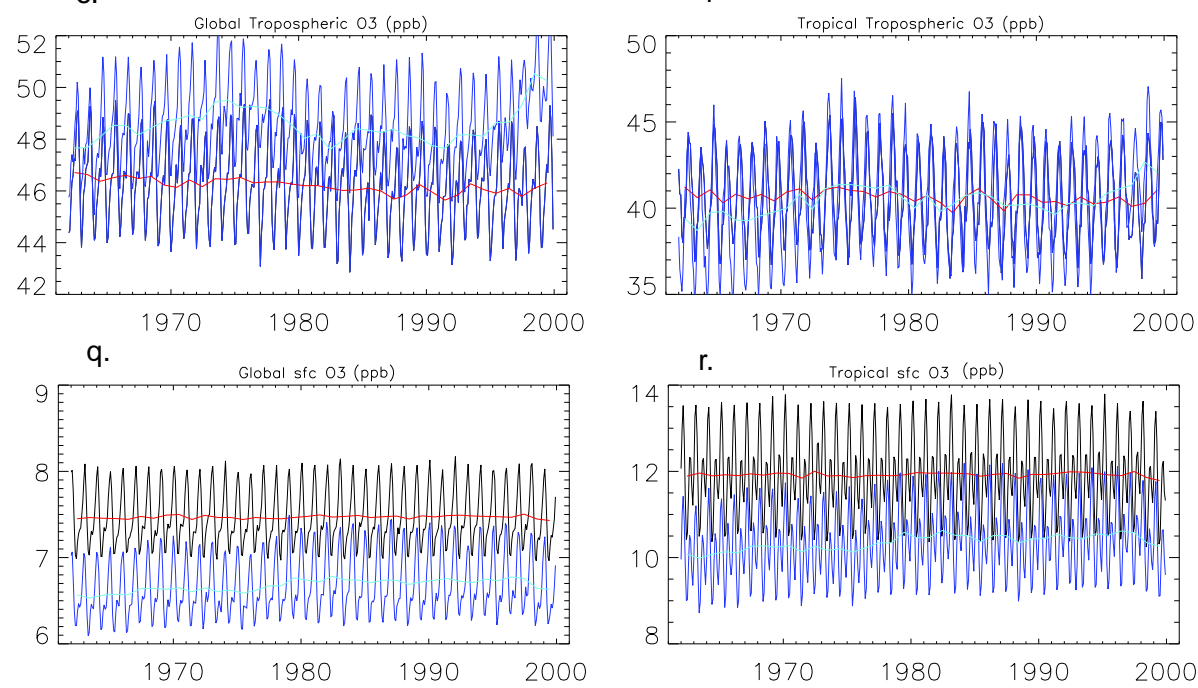

Fig. 5. Continued.

with the methane budget. In a study of the methane budget Wang et al. (2004) found $\mathrm{OH}$ variations on the order of a few percent using fixed stratospheric ozone columns (as were used here). The results from both NCEPC and CAMC, both driven solely by meteorological variability, are consistent with the low end of $\mathrm{OH}$ variability.

\subsection{Relation to meteorological indexes of variability}

Table 3 gives the correlation between El Niño and the analyzed fields averaged either globally or in the tropics. CAMC and NCEPC give different responses. Except for tropical surface temperature, none of the analyzed variables in NCEPC is significantly correlated with El Niño. In contrast, besides the significant correlation between surface temperature and El Niño, CAMC also has significant correlations with tropical planetary boundary layer height, lightning $\mathrm{NO}_{\mathrm{x}}, \mathrm{HNO}_{3}$

and ozone. The negative correlation with the ozone burden in CAMC is consistent with the results of Doherty et al. (2006) based on the STOCHEM model coupled with the Hadley Centre GCM. However, Doherty et al. (2006) also find a strong tropical and global correlation between the tropospheric $\mathrm{OH}$ burden and $\mathrm{El}$ Niño, which we find in neither simulation. The different chemical responses to El Niño, which range from the very weak response in NCEPC to the large global response reported in Doherty et al. (2006), are not well understood, but would benefit from simulations across a wide number of models. Our simulations suggest that neither globally or tropically averaged $\mathrm{OH}$ is driven by the meteorological variability associated with El Niño. Based on observations (Prinn et al., 2001) suggests a tenuous negative relationship between $\mathrm{El}$ Niño and $\mathrm{OH}$, although this conclusion is coupled with changes in emissions. Dentener et al. (2003) finds little connection between OH and ENSO. 
Table 3. Global and Tropical $\left(-30^{\circ} \mathrm{S}-30^{\circ} \mathrm{N}\right)$ correlations between various variables in the CAMC and NCEPC simulations with El Niño. Three dimensional fields are density weighted, annually averaged and averaged between the surface and $280 \mathrm{hPa}$. Only results significant at the $95 \%$ confidence level are shown where results significant at $99 \%$ are bold faced. Three dimension quantities evaluated at the surface are prefixed with Sfc.

\begin{tabular}{|c|c|c|c|c|}
\hline & \multicolumn{2}{|c|}{ Tropics } & \multicolumn{2}{|c|}{ Global } \\
\hline & NCEPC & CAMC & NCEPC & CAMC \\
\hline $\mathrm{O}_{3}$ & NS & -0.78 & NS & -0.49 \\
\hline $\mathrm{CO}$ & NS & NS & NS & NS \\
\hline $\mathrm{OH}$ & NS & NS & NS & NS \\
\hline $\mathrm{HNO}_{3}$ & NS & 0.50 & NS & NS \\
\hline $\mathrm{Sfc} \mathrm{O}_{3}$ & NS & NS & NS & NS \\
\hline Sfc T & 0.48 & 0.59 & NS & NS \\
\hline $\mathrm{Sfc}_{\mathrm{JNO}_{2}}$ & NS & NS & NS & NS \\
\hline $\mathrm{LNO}^{\mathrm{a}}$ & NS & -0.43 & NS & NS \\
\hline $\mathrm{PBLH}^{\mathrm{b}}$ & NS & 0.86 & NS & 0.65 \\
\hline PRECT $^{\mathrm{c}}$ & NS & NS & NS & NS \\
\hline$Q^{d}$ & NS & NS & NS & NS \\
\hline
\end{tabular}

${ }^{\mathrm{a}}$ Source of lightning odd nitrogen in $\mathrm{Tg} \mathrm{N} \mathrm{yr}^{-1}$; ${ }^{\mathrm{b}}$ Planetary Boundary Layer Height; ${ }^{\mathrm{c}}$ Total Precipitation; ${ }^{\mathrm{d}}$ Water Vapor

Surface ozone is negatively correlated with the NAO in both CAMC and NCEPC (Table 4). These correlations are consistent with the negative ozone correlations north of $50^{\circ} \mathrm{N}$ found in Hess and Lamarque (2007). With the exception of precipitable water in CAMC, no other variable has a significant correlation with the $\mathrm{NAO}$ in the $\mathrm{NH}$. On the global scale $\mathrm{OH}, \mathrm{CO}$ and lightning $\mathrm{NO}_{\mathrm{x}}$ are correlated with the NAO index in CAMC, suggesting the influence of the NAO may extend into the tropics.

\subsection{Correlations between NCEP and CAMC}

Figure 5 suggests that the timeseries for many of the variables are correlated between CAMC and NCEPC on interannual timescales. The obvious reason for this is because the temporally varying SSTs used in the CAMC simulation (determined from measurements) provide a strong external forcing on the simulation, in part due to the strong relation between SST and integrated water vapor (Trenberth et al., 2005). Soden (2000) shows that AMIP (Atmospheric Model Intercomparison Project) simulations forced with observed tropical SSTs capture the observed tropical variations in temperature and water vapor.

The inter-model correlation between the variables in CAMC and NCEPC are given in Table 5. In the tropics, there are strong correlations between the two simulations in temperature, water vapor, lightning $\mathrm{NO}_{\mathrm{x}}, \mathrm{OH}$ and $\mathrm{CO}$. The relation between these variables is explored in more detail in Sect. 5.5. Changes in tropical precipitation do not corre-
Table 4. Global and Northern Hemisphere $\left(30-90^{\circ} \mathrm{N}\right)$ correlations between various variables in the CAMC and NCEPC simulations with NAO. Three dimensional fields are density weighted, annually averaged and averaged between the surface and $280 \mathrm{hPa}$. Only results significant at the $95 \%$ are shown, and results significant at $99 \%$ are bold faced. Three dimension quantities evaluated at the surface are prefixed with Sfc.

\begin{tabular}{lcccc}
\hline & \multicolumn{2}{c}{ Northern Hemisphere } & \multicolumn{2}{c}{ Global } \\
\hline & NCEPC & CAMC & NCEPC & CAMC \\
\hline $\mathrm{O}_{3}$ & NS & NS & NS & NS \\
$\mathrm{CO}$ & NS & NS & NS & $\mathbf{- 0 . 5 2}$ \\
$\mathrm{OH}$ & NS & NS & NS & 0.42 \\
$\mathrm{HNO}_{3}$ & NS & NS & NS & NS \\
$\mathrm{Sfc} \mathrm{O}_{3}$ & -0.46 & -0.49 & NS & NS \\
$\mathrm{Sfc} \mathrm{T}$ & NS & NS & NS & NS \\
$\mathrm{Sfc} \mathrm{JNO}_{2}$ & NS & NS & NS & NS \\
LNO $^{\mathrm{a}}$ & NS & NS & NS & $\mathbf{0 . 6 3}$ \\
PBLH $^{\mathrm{b}}$ & NS & NS & NS & NS \\
PRECT $^{\mathrm{c}}$ & NS & NS & NS & NS \\
Q $^{\text {d }}$ & NS & 0.44 & NS & NS \\
\hline
\end{tabular}

a Source of lightning odd nitrogen in $\mathrm{Tg} \mathrm{N} \mathrm{yr}^{-1}$; ${ }^{\mathrm{b}}$ Planetary Boundary Layer Height; ${ }^{\mathrm{c}}$ Total Precipitation; ${ }^{\mathrm{d}}$ Water Vapor

late strongly with changes in SST in agreement with Soden (2000). For the most part the correlation is the same when the variables are averaged global or solely for the $\mathrm{NH}$, but not necessarily for the $\mathrm{SH}$. The correlations between the simulations for ozone, $\mathrm{HNO}_{3}$ and $\mathrm{JNO}_{2}$ are generally low, suggesting these fields are not strongly regulated by sea-surface temperature.

\subsection{Trends in global concentration burdens}

Trends in the globally averaged variables in NCEPC and CAMC are given in Table 6. The global long-term trends are significantly different between the two simulations. In accord with observations CAMC has a significant trend in temperature (approximately $1 \% \mathrm{yr}^{-1}$ ) and precipitable water (approximately $0.3 \% \mathrm{yr}^{-1}$ ). In an analysis based on satellite observations Trenberth et al. (2005) finds precipitable water has increased over the ocean by approximately $0.13 \pm 0.03 \% \mathrm{yr}^{-1}$ between 1988 and 2003. Ross and Elliott (2001) find water vapor increases over most NH radiosonde stations with reasonable quality records between 1973 and 1995. NCEPC shows a trend in neither temperature nor water vapor. The NCEP reanalysis has been shown to have major problems in capturing the trend of water vapor over the oceans when compared with data from the special sensor microwave imager (SSM/I) (Trenberth et al., 2005). Both simulations show a significant increase in precipitation ranging from approximately $0.06 \%$ decade $^{-1}$ in CAMC to $2 \%$ decade $^{-1}$ in NCEPC. Wentz et al. (2007) report a 
Table 5. Correlations between the NCEPC and CAMC simulations: global, tropical $\left(-30^{\circ}-30^{\circ}\right), \mathrm{NH}\left(30^{\circ}-90^{\circ}\right)$ and $\mathrm{SH}\left(-90^{\circ}--30^{\circ}\right)$ correlations between the annually averaged integrated variables in the two simulations. Three dimensional fields are density weighted and averaged between the surface and $280 \mathrm{hPa}$. Only results significant at the $95 \%$ are shown. Results significant at the 99th percentile are shown in bold. Three dimension quantities evaluated at the surface are prefixed with Sfc.

\begin{tabular}{|c|c|c|c|c|}
\hline & Global & Tropical & N.H. & S.H. \\
\hline $\mathrm{O}_{3}$ & NS & NS & NS & NS \\
\hline $\mathrm{CO}$ & 0.64 & 0.66 & 0.69 & NS \\
\hline $\mathrm{OH}$ & 0.79 & 0.68 & 0.74 & 0.57 \\
\hline $\mathrm{HNO}_{3}$ & NS & NS & NS & NS \\
\hline $\mathrm{Sfc} \mathrm{O}_{3}$ & -0.42 & NS & -0.36 & NS \\
\hline Sfc T & NS & 0.81 & NS & NS \\
\hline Sfc $\mathrm{JNO}_{2}$ & NS & NS & NS & NS \\
\hline $\mathrm{LNO}^{\mathrm{a}}$ & 0.70 & 0.62 & 0.46 & NS \\
\hline $\mathrm{PBLH}^{\mathrm{b}}$ & NS & NS & NS & NS \\
\hline PRECT $^{\mathrm{c}}$ & 0.58 & NS & NS & NS \\
\hline$Q^{d}$ & 0.66 & 0.67 & 0.55 & 0.56 \\
\hline
\end{tabular}

${ }^{\mathrm{a}}$ Source of lightning odd nitrogen in $\mathrm{Tg} \mathrm{N} \mathrm{yr}^{-1} ;{ }^{\mathrm{b}}$ Planetary Boundary Layer Height; ${ }^{c}$ Total Precipitation; ${ }^{\mathrm{d}}$ Water Vapor

measured increase of $1.4 \pm 0.5 \%$ decade $^{-1}$ between 1987 and 2006. The photolysis rate of $\mathrm{NO}_{2}$ also shows a significant decrease in CAMC $\left(-0.04 \% \mathrm{yr}^{-1}\right)$ but not in NCEPC, suggesting an associated increase in cloudiness in CAMC. Measured cloudiness increases have been reported over the US between 1976 and 2004 (e.g., see Dai et al., 2006, and references therein) and over the oceans between 1952 and 1995 (Norris, 1999). Lightning $\mathrm{NO}_{\mathrm{x}}$ emissions increase in both CAMC and NCEPC.

Significant differences also are evident in the trend of the chemical variables in NCEPC and CAMC. Some of these differences are clearly linked to the differences in the trend of the meteorological variables. As expected, the trend in water vapor in CAMC leads to a positive trend in $\mathrm{OH}$ and a negative trend in $\mathrm{CO}$. We find an $\mathrm{OH}$ trend of $0.05 \%$ per year in CAMC, and no significant trend in NCEPC. In a set of methane simulations Wang et al. (2004) found an $\mathrm{OH}$ trend of $0.16 \% / \mathrm{yr}$ with no change in the stratospheric ozone column and $0.64 \%$ year taking stratospheric ozone variations into account. Other modeling studies find $\mathrm{OH}$ trends of $0.43 \% \mathrm{yr}^{-1}$ and $0.2 \pm 0.06 \% \mathrm{yr}^{-1}$ (Karlsdóttir and Isaksen, 2000; Dentener et al., 2003, respectively) when taking variations in emissions into account, where the latter study allowed for evolving stratospheric ozone. Trends in $\mathrm{OH}$ inferred from methyl chloroform measurements are somewhat ambiguous. Prinn et al. (2005) suggest a very small trend in $\mathrm{OH}\left(0.2 \%[-0.4,+0.8] \mathrm{yr}^{-1}\right)$ between 1979 and 2003. Bousquet et al. (2006) gives a trend of $-0.7 \% \mathrm{yr}^{-1}$, and (Krol and Lelieveld, 2003) find essentially no trend.
Table 6. Change in globally averaged selected variables with year in CAMC and NCEPC. Three dimensional fields are density weighted and averaged between the surface and $280 \mathrm{hPa}$. Only results significant at the $95 \%$ are shown. Results significant at the 99th percentile are shown in bold. Three dimension quantities evaluated at the surface are prefixed with Sfc. The units of the "change"/yr are the units given for each variable.

\begin{tabular}{|c|c|c|}
\hline & CAMC & NCEPC \\
\hline $\mathrm{O}_{3}$ (ppbv) & NS & $7.1710^{-2}$ \\
\hline $\mathrm{CO}$ (ppbv) & $-3.2410^{-5}$ & NS \\
\hline $\mathrm{OH}\left(\right.$ mole $/$ mole $\left.\times 10^{15}\right)$ & $5.2610^{-2}$ & NS \\
\hline $\mathrm{HNO}_{3}$ (pptv) & NS & $-1.1810^{-1}$ \\
\hline $\mathrm{Sfc} \mathrm{O}_{3}$ (ppbv) & $-9.1010^{-3}$ & $4.8010^{-2}$ \\
\hline Sfc T (C) & $1.1110^{-2}$ & NS \\
\hline $\mathrm{Sfc} \mathrm{JNO}_{2}\left(\mathrm{~s}^{-1} \times 10^{-3}\right)$ & $-4.1410^{-4}$ & NS \\
\hline $\mathrm{LNO}(\mathrm{TgN} / \mathrm{yr})^{\mathrm{a}}$ & $7.1010^{-3}$ & $1.5210^{-2}$ \\
\hline $\operatorname{PBLH}(\mathrm{m})^{\mathrm{b}}$ & NS & $2.6010^{-1}$ \\
\hline $\operatorname{PRECT}(\mathrm{mm} / \text { day })^{\mathrm{c}}$ & $1.4010^{-3}$ & $5.2010^{-3}$ \\
\hline $\mathrm{Q}(\mathrm{g} / \mathrm{kg})^{\mathrm{d}}$ & $3.3010^{-3}$ & NS \\
\hline
\end{tabular}

a Source of lightning odd nitrogen in $\mathrm{Tg} \mathrm{N} \mathrm{yr}^{-1}$; b Planetary Boundary Layer Height; ${ }^{\mathrm{c}}$ Total Precipitation; ${ }^{\mathrm{d}}$ Water Vapor

Trends in $\mathrm{HNO}_{3}$ may be affected by both trends in the production of $\mathrm{HNO}_{3}$ (through trends in $\mathrm{OH}$ and $\mathrm{NO}_{\mathrm{x}}$ ) and trends in its loss, primarily through precipitation. NCEPC (but not CAMC) has a negative trend in $\mathrm{HNO}_{3}\left(-1 \% \mathrm{yr}^{-1}\right)$, consistent with the increasing trend in precipitation. Note that in CAMC both precipitation and $\mathrm{OH}$ increase, possibly leading to offsetting forcings on the concentration of $\mathrm{HNO}_{3}$.

Interestingly, NCEPC has significant interdecadal variability in total tropospheric ozone, as well as a significant trend $\left(7.2 \times 10^{-2} \mathrm{ppbv} \mathrm{yr}^{-1}\right)$, not captured in CAMC. This trend is also apparent in surface ozone $\left(4.8 \times 10^{-2} \mathrm{pbbv} \mathrm{yr}^{-1}\right)$. Most of the ozone change occurs after 1990, with ozone changes of approximately $0.25 \mathrm{ppbvyr}^{-1}$ or $5 \% \mathrm{yr}^{-1}$ between 1990 and the end of the simulaton. In the last thirty years the ozone trends have shown considerable regional and temporal variability (Oltmans et al., 2006). However, a number of remote sites with frequent measurements have shown significant increases during the 1990s. Measurements at high altitude sites over Europe (the Jungfraujoch and Zugspitze) show large ozone increases since the early 1990s (Ordonez et al., 2007) with seasonal ozone trends between 0.15 and $0.25 \mathrm{ppbv} \mathrm{yr}^{-1}$ (when one excludes the summer season). Zbinden et al. (2006) obtains a linear ozone increase from the MOZAIC programme (Measurements of Ozone, Water Vapour, Carbon Monoxide and Nitrogen Oxides by In-Service Airbus Aircraft) between 1994 and 2002 of $0.7 \% \mathrm{yr}^{-1}$ over Frankfurt, $0.8 \% \mathrm{yr}^{-1}$ over Japan, $1.1 \% / \mathrm{yr}$ over New York and $1.6 \% \mathrm{yr}^{-1}$ over Paris. Jaffe and Ray (2007) examined ozone trends from 11 rural and remote sites 
Table 7. Correlation between the annual averaged global timeseries of analyzed variables in CAMC from 1979-1999. Three dimensional variables have been density weighted between the surface and $280 \mathrm{hPa}$. Three dimension quantities evaluated at the surface are prefixed with Sfc.

\begin{tabular}{lccccccccccc}
\hline & $\mathrm{Sfc} \mathrm{T}^{\mathrm{T}}$ & $\mathrm{PBLH}^{\mathrm{a}}$ & $\mathrm{PRECT}^{\mathrm{b}}$ & $\mathrm{Q}^{\mathrm{c}}$ & $\mathrm{LNO}^{\mathrm{d}}$ & $\mathrm{JNO}_{2}$ & $\mathrm{Sfc}_{3}$ & $\mathrm{O}_{3}$ & $\mathrm{OH}$ & $\mathrm{CO}$ & $\mathrm{HNO}_{3}$ \\
\hline $\mathrm{Sfc} \mathrm{T}$ & $\times$ & 0.45 & 0.89 & 0.88 & 0.55 & -0.75 & -0.60 & -0.32 & 0.75 & -0.56 & 0.42 \\
$\mathrm{PBLH}^{\mathrm{a}}$ & & $\times$ & 00.34 & 00.43 & -0.20 & -0.41 & -0.14 & -0.57 & 0.12 & 0.10 & 0.32 \\
$\mathrm{PRECT}^{\mathrm{b}}$ & & & $\times$ & 0.91 & 0.72 & -0.80 & -0.48 & -0.14 & 0.91 & -0.78 & 0.57 \\
$\mathrm{Q}^{\mathrm{c}}$ & & & & $\times$ & 0.65 & -0.83 & -0.64 & -0.36 & 0.88 & -0.72 & 0.50 \\
$\mathrm{LNO}^{\mathrm{d}}$ & & & & & $\times$ & -0.45 & -0.43 & 0.28 & 0.85 & -0.85 & 0.23 \\
$\mathrm{JNO}_{2}$ & & & & & & $\times$ & 0.27 & 0.32 & -0.72 & 0.55 & -0.48 \\
$\mathrm{Sfc}_{3}$ & & & & & & & $\times$ & 0.60 & -0.40 & 0.32 & 0.17 \\
$\mathrm{O}_{3}$ & & & & & & & & $\times$ & 0.08 & -0.21 & -0.12 \\
$\mathrm{OH}$ & & & & & & & & & $\times$ & -0.91 & 0.53 \\
$\mathrm{CO}$ & & & & & & & & & & $\times$ & -0.41 \\
$\mathrm{HNO}_{3}$ & & & & & & & & & & & $\times$ \\
\hline
\end{tabular}

${ }^{a}$ Planetary Boundary Layer Height; ${ }^{\mathrm{b}}$ Total Precipitation; ${ }^{\mathrm{c}}$ Water Vapor; ${ }^{\mathrm{d}}$ Source of lightning odd nitrogen in $\mathrm{Tg} \mathrm{N} \mathrm{yr}{ }^{-1}$

in the north and western US, with significant ozone trends between approximately 0.05 and $0.5 \mathrm{ppbv} \mathrm{yr}^{-1}$ at 9 out of the 11 sites. Simmonds et al. (2004) reports an ozone trend at the Mace Head site between 1987 and 2003 of $0.49 \mathrm{ppbv} \mathrm{yr}^{-1}$. The results with NCEP suggest a substantial ozone increase during the 1990s solely due to meteorological variability The cause of this ozone increase is currently being investigated (Hess et al., 2009, in preparation), but is outside the scope of the present work.

\subsection{Correlation amongst variables}

Correlation between the global timeseries (from 1979-1999) of the different analyzed variables in CAMC and NCEPC are given in Tables 7 and 8, respectively. In CAMC (Table 7) the correlation between many of the variables is highly significant. Surface temperature and water vapor are highly correlated with every variable except for ozone. The relationships between the variables in NCEPC (Table 8) are generally much weaker. In NCEPC surface temperature is generally not as tightly coupled to the rest of the system as in CAMC. The lack of a correlation between surface temperature and precipitation is particularly notable. Correlations between ozone and the other analyzed variables also differ between CAMC and NCEPC. Variations in tropospheric ozone are significantly correlated with the many of the other analyzed variables in NCEPC and in particular with lightning $\mathrm{NO}_{\mathrm{x}}$ emissions. The correlations in CAMC are much weaker.

To assist in the analysis of Tables 7 and 8 , we have made a principal component analysis (PCA) of the global timeseries of the analyzed variables. Table 9 gives the correlations between the first and second principal component and the timeseries of each variable. The first global principal component in CAMC explains $57 \%$ of the interannual variability. This mode explains most of the variance in surface temperature, water vapor, cloudiness, precipitation, lightning $\mathrm{NO}_{\mathrm{x}}$ emissions, $\mathrm{OH}$ and $\mathrm{CO}$. This mode is strongly correlated with year, consistent with the observed trend in water vapor and cloudiness (see Sect. 5.4). While the 1st EOF in CAMC is not significantly correlated with either El Niño or ozone, the second principal component is correlated with both. This is consistent with the strong relationship between El Niño and total ozone in CAM (Table 3). The 2nd principal component explains approximately $20 \%$ of the total variability and most of the ozone variability.

In NCEP the 1st global principal component explains approximately $42 \%$ of the variance and has a -0.33 correlation with year. This principal component is similar to the 1st principal component in CAM except it is strongly correlated with ozone (both at the surface and the tropospheric column), but is not correlated with precipitation. The ozone variations are such that increases in water vapor correspond to increases in ozone, the opposite response that might be expected from climate forcing. The latter signal is most likely the result of the pronounced increase in $\mathrm{O}_{3}$ since 1990 in NCEPC (see Fig. 5). The second principal component in NCEP explains $29 \%$ of the variance and has a -0.67 correlation with year. This mode explains much the variation in precipitation and $\mathrm{HNO}_{3}$ in CAMC. It has little resemblance to the 2nd principal component in CAMC. Neither principal component is correlated with El Niño in NCEPC, consistent with the results presented in Table 3.

In both NCEPC and CAMC similar principal components are also apparent when analyzing the fields only within the tropics (not shown). In both models the correlation between the first mode of variability in the global and tropical analysis is greater than 0.9 . This suggests these modes are likely to be driven through tropical variability, although not by El Niño. 
Table 8. As in Table 7, but for NCEPC.

\begin{tabular}{lccccccccccc}
\hline & $\mathrm{Sfc} \mathrm{T}$ & $\mathrm{PBLH}^{\mathrm{a}}$ & $\mathrm{PRECT}^{\mathrm{b}}$ & $\mathrm{Q}^{\mathrm{c}}$ & $\mathrm{LNO}^{\mathrm{d}}$ & $\mathrm{JNO}_{2}$ & $\mathrm{Sfc} \mathrm{O}_{3}$ & $\mathrm{O}_{3}$ & $\mathrm{OH}$ & $\mathrm{CO}^{2} \mathrm{HNO}_{3}$ \\
\hline $\mathrm{Sfc} \mathrm{T}$ & $\times$ & 0.04 & -0.15 & 0.79 & 0.20 & -0.40 & -0.14 & -0.06 & 0.63 & -0.47 & 0.38 \\
$\mathrm{PBLH}^{\mathrm{a}}$ & & $\times$ & 0.11 & -0.05 & 0.32 & -0.48 & 0.50 & 0.47 & 0.36 & -0.44 & 0.40 \\
$\mathrm{PRECT}^{\mathrm{b}}$ & & & $\times$ & -0.11 & 0.48 & 0.37 & 0.55 & 0.49 & 0.09 & 0.04 & -0.69 \\
$\mathrm{Q}^{\mathrm{c}}$ & & & & $\times$ & 0.49 & -0.28 & 0.07 & 0.19 & 0.81 & -0.58 & 0.35 \\
$\mathrm{LNO}^{\mathrm{d}}$ & & & & & $\times$ & 0.12 & 0.82 & 0.88 & 0.70 & -0.51 & -0.09 \\
$\mathrm{JNO}_{2}$ & & & & & & $\times$ & 0.16 & 0.07 & -0.48 & 0.53 & -0.69 \\
$\mathrm{Sfc}_{3}$ & & & & & & & $\times$ & 0.95 & 0.41 & -0.40 & -0.12 \\
$\mathrm{O}_{3}$ & & & & & & & & $\times$ & 0.57 & -0.53 & -0.05 \\
$\mathrm{OH}$ & & & & & & & & & $\times$ & -0.85 & 0.39 \\
$\mathrm{CO}$ & & & & & & & & & $\times$ & 0.52 \\
$\mathrm{HNO}_{3}$ & & & & & & & & & $\times$ & $\times$ \\
\hline
\end{tabular}

a Planetary Boundary Layer Height; ${ }^{\mathrm{b}}$ Total Precipitation; ${ }^{\mathrm{c}}$ Water Vapor; ${ }^{\mathrm{d}}$ Source of lightning odd nitrogen in $\mathrm{Tg} \mathrm{N} \mathrm{yr}{ }^{-1}$

Table 9. Correlation coefficient of the time series from the PCA analysis of the globally averaged variables with the globally and annually averaged time series of each variable, with El Nino, with NAO and with year. The percent of variability (\%) explained by each EOF is also given. Three dimension quantities evaluated at the surface are prefixed with Sfc.

\begin{tabular}{llccc}
\hline & \multicolumn{2}{c}{ CAMC } & \multicolumn{2}{c}{ NCEPC } \\
\hline & 1st EOF & 2nd EOF & 1st EOF & 2nd EOF \\
\hline $\mathrm{O}_{3}$ & 0.23 & 0.89 & -0.74 & -0.6 \\
$\mathrm{CO}$ & 0.8 & -0.5 & 0.87 & -0.22 \\
$\mathrm{OH}$ & -0.94 & 0.31 & -0.94 & 0.16 \\
$\mathrm{HNO}_{3}$ & -0.54 & -0.02 & -0.41 & 0.74 \\
$\mathrm{Sfc} \mathrm{O}_{3}$ & 0.58 & 0.33 & -0.64 & -0.69 \\
$\mathrm{Sfc} \mathrm{T}$ & -0.89 & -0.21 & -0.51 & 0.53 \\
$\mathrm{Sfc} \mathrm{JNO}_{2}$ & 0.85 & 0.2 & 0.43 & -0.67 \\
$\mathrm{LNO}^{\mathrm{a}}$ & -0.74 & 0.56 & -0.79 & -0.51 \\
$\mathrm{PBLH}^{\mathrm{b}}$ & -0.33 & -0.74 & -0.55 & -0.05 \\
$\mathrm{PRECT}^{\mathrm{c}}$ & -0.97 & 0.04 & -0.17 & -0.8 \\
$\mathrm{Q}^{\mathrm{d}}$ & -0.97 & -0.15 & -0.68 & 0.36 \\
El Nino & -0.08 & -0.67 & 0.13 & 0.01 \\
NAO & -0.37 & 0.32 & 0.11 & 0.21 \\
Year & -0.58 & -0.07 & -0.33 & -0.67 \\
$\%$ & 57.0 & 20.15 & 42.2 & 29.5 \\
\hline
\end{tabular}

${ }^{\text {a }}$ Source of lightning odd nitrogen in $\mathrm{Tg} \mathrm{N} \mathrm{yr}^{-1}$; ${ }^{\mathrm{b}}$ Planetary Boundary Layer Height; ${ }^{c}$ Total Precipitation; ${ }^{\mathrm{d}}$ Water Vapor.

\section{Sensitivity to changes in climate variables}

Slingo et al. (2000), following Cess et al. (1990) used the natural interannual variability of the climate system to give an indication of the response of the system to the strength of the water vapor feedback. Here we use a similar methodology to explore how the tropospheric burden of select species responds to changes in surface temperature. Across a wide
Table 10. Percent change in variable with change in temperature for the CAMC and NCEPC simulations. Also shown are results for a climate change simulation (see Murazaki and Hess, 2006). See text for further explanation. Three dimension quantities evaluated at the surface are prefixed with Sfc.

\begin{tabular}{llcc}
\hline & CAMC & NCEPC & CAM 2090-CAM 1990 \\
\hline $\mathrm{O}_{3}$ & $-1.2 \pm 0.78$ & $\mathrm{NS}$ & $-1.1 \pm 0.3$ \\
$\mathrm{CO}$ & $-2.5 \pm 0.9$ & $-1.8 \pm 0.8$ & $-1.3 \pm 0.4$ \\
$\mathrm{OH}$ & $6.2 \pm 1.3$ & $6.3 \pm 1.8$ & $3.9 \pm 0.4$ \\
$\mathrm{HNO}_{3}$ & $3.7 \pm 1.8$ & $3.9 \pm 2.1$ & $1.7 \pm 0.6$ \\
$\mathrm{Sfc} \mathrm{O}_{3}$ & $-2.1 \pm 0.65$ & $\mathrm{NS}$ & $-2.3 \pm 0.2$ \\
$\mathrm{Sfc} \mathrm{JNO}_{2}$ & $-1.2 \pm 0.25$ & $-1.1 \pm 0.6$ & $\mathrm{NS}$ \\
$\mathrm{LNO}^{\mathrm{a}}$ & $12 \pm 4.1$ & $\mathrm{NS}$ & $9.6 \pm 2.5$ \\
$\mathrm{PBLH}^{\mathrm{b}}$ & $1.3 \pm 0.59$ & $\mathrm{NS}$ & $-0.7 \pm 0.1$ \\
$\mathrm{PRECT}^{\mathrm{c}}$ & $4.2 \pm 0.54$ & $\mathrm{NS}$ & $2.5 \pm 0.2$ \\
$\mathrm{Q}^{\mathrm{d}}$ & $9.0 \pm 1.1$ & $7.0 \pm 1.2$ & $7.3 \pm 0.3$ \\
\hline
\end{tabular}

a Source of lightning odd nitrogen; ${ }^{b}$ Planetary Boundary Layer Height; ${ }^{\mathrm{c}}$ Total Precipitation;

d Water Vapor

spectrum of climate models changes in tropospheric water vapor show a robust relationship to changes in surface temperature, following the Clausius Clapeyron relationship of 7\%/K (Held and Soden, 2006). This robust measure of climate change has proven to be useful in understanding the atmospheric response to climate change.

Figure 6 gives the percentage change of selected variables versus temperature in the CAMC and NCEPC simulations. The linear slope of the percentage change in the selected model variables against temperature change is summarized in Table 10. Table 10 also gives the percentage change of selected variables versus temperature when comparing a 20902100 simulation with a 1990-2000 simulation. The latter simulations are described in Murazaki and Hess (2006), and 

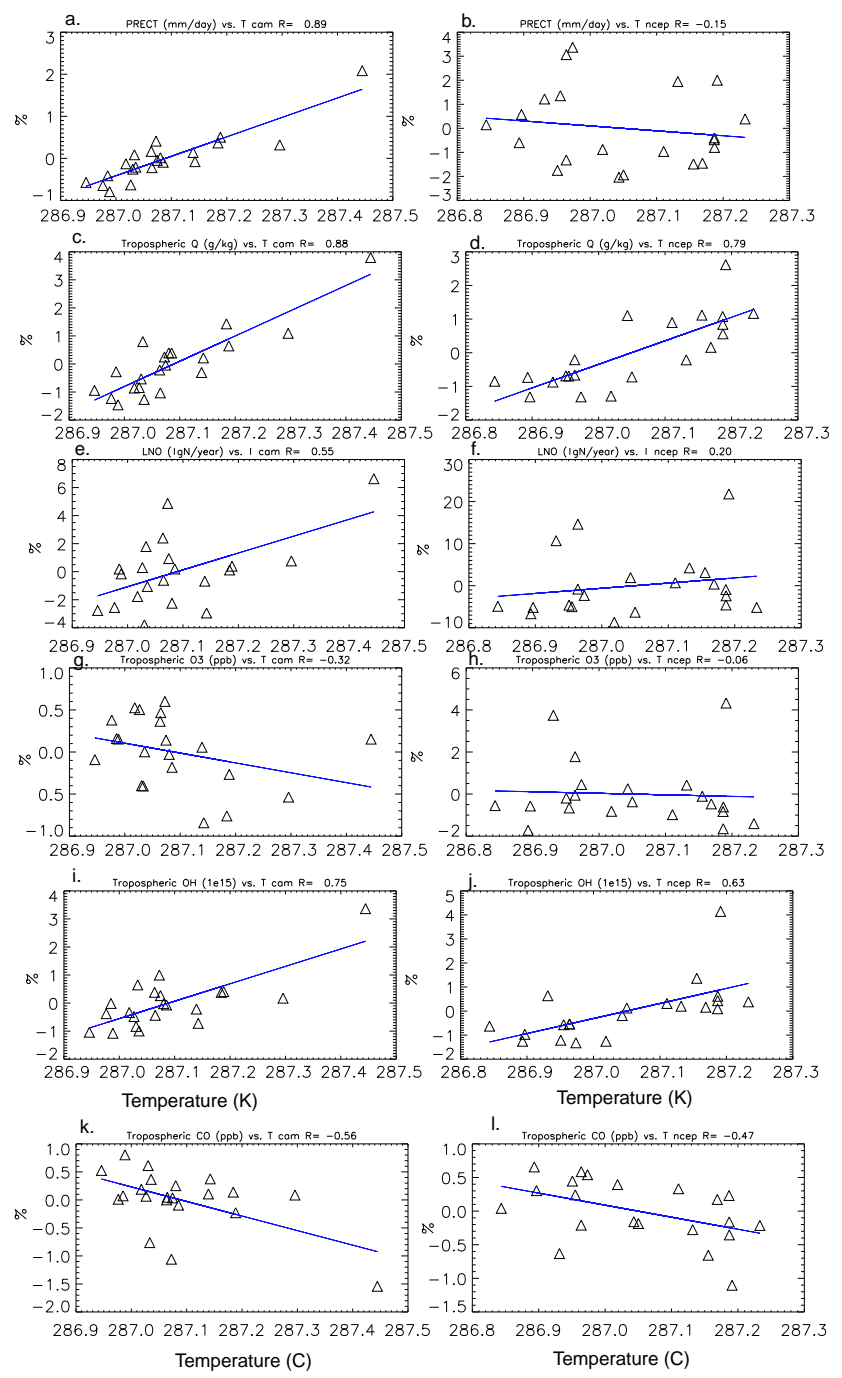

Fig. 6. Percent change in quantity versus temperature in NCEPC and CAMC. Three dimensional fields are area weighted and averaged over the troposphere using a density weighting, 2 dimensional fields are area weighted. Fields for CAMC and NCEPC, respectively for (a) and (b) Precipitation; (c) and (d) Water Vapor; (e) and (f) $\mathrm{LNO}$; (g) and (h) $\mathrm{O}_{3}$; (i) and (j) $\mathrm{CO}$; and (k) and (l) $\mathrm{OH}$.

their setup is similar, although not identical to the simulations described here. The sensitivity to temperature change is calculated between all pairs of model years in the two simulations: one year taken from the future simulation and one year from the 20th century simulation (i.e., 100 different pairs). The mean and standard deviation of these individual sensitivity calculations is given in Table 10 .

The error bounds for long term and short term changes in CAM overlap for $\mathrm{O}_{3}, \mathrm{CO}, \mathrm{LNO}$, and PBLH; they do not overlap for $\mathrm{OH}$, the surface photolysis of rate $\mathrm{NO}_{2}$, or precipitation. Differences between the short and long-term responses in CAM are not entirely unexpected. One might argue that while the present day variability is largely determined by tropical variability, future changes in temperature are expected to be largely concentrated in the high latitudes. The trends also do not overlap for water vapor. The shortterm sensitivity of water vapor to temperature in CAMC is unexpectedly high $(9 \% / \mathrm{K})$. In contrast the long-term change over the 21st century is consistent with Clausius-Clapeyron scaling (7\%/K). Held and Soden (2006) show that the AR4 models obtain a response just slightly larger than one would expect from Clausius-Clapeyron scaling.

The response of precipitation to surface temperature differs considerably between the CAMC and NCEPC simulations, a result consistent with the EOF analysis (see Table 9). CAMC gives a strong correlation between precipitation and global surface temperature with a slope of $4.6 \% / \mathrm{K}$, while NCEPC shows no significant relation. The AR4 models show substantial scatter in the relation between surface temperature and precipitation, with a median slope of $1.7 \% / \mathrm{K}$ (Held and Soden, 2006). The study of Wentz et al. (2007), based on satellite observations, suggests precipitation increased by 6\%/K between 1987 and 2006.

The production or loss of a number of chemical variables directly relate to water vapor. In particular, the dominant production of $\mathrm{HO}_{\mathrm{x}}$ occurs through reaction of $\mathrm{O}^{1} \mathrm{D}$ and water vapor. If one approximates the $\mathrm{OH}$ steady-state concentration as a balance between its primary production and loss pathways, ignoring the interconversions between $\mathrm{OH}$ and $\mathrm{HO}_{2}$, and assuming no correlation between ozone and water vapor (Q), then:

$[\mathrm{OH}]=\frac{2 j_{1} k_{3}}{k_{2}[M] L}\left[\mathrm{O}_{3}\right][\mathrm{Q}]$

where $[\mathrm{OH}],\left[\mathrm{O}_{3}\right]$ and $[\mathrm{Q}]$ are the average global concentrations, $j_{1}$ is the photolysis rate of $\mathrm{O}_{3}$ to $\mathrm{O}^{1} \mathrm{D}, k_{3}$ is the reaction rate of $\mathrm{O}_{1} \mathrm{D}$ with $\mathrm{H}_{2} \mathrm{O}, k_{2}$ the reaction of $\mathrm{O}^{1} \mathrm{D}$ with an inert atmospheric molecule $(M), L$ is the loss of $\mathrm{OH}$ through reaction with any other chemical species. Taking the derivative with respect to temperature $(T)$, and assuming everything remains constant except water vapor, one obtains:

$\delta[\mathrm{OH}] /[\mathrm{OH}]=\delta[\mathrm{Q}] /[\mathrm{Q}] \cong 0.07 \delta T$

The relation with temperature follows from the expected Clausius-Clapeyron scaling. Changes in globally averaged temperature explain $56 \%$ and $40 \%$ of the interannual variability of $\mathrm{OH}$ in CAMC and NCEPC, respectively (Fig. 6). In both simulations the percent increase in $\mathrm{OH}$ is approximately $6.2 \% / \mathrm{K}$, somewhat less than one might expect from Clausius-Clapeyron scaling. Changes in cloudiness, lightning $\mathrm{NO}_{\mathrm{x}}$, and ozone will obviously affect the overall scaling.

$\mathrm{HNO}_{3}$, whose primary production is through the reaction of $\mathrm{OH}$ and $\mathrm{NO}_{2}$ might also be expected to exhibit 
Clausius-Clapeyron scaling. However, the increase of $\mathrm{HNO}_{3}$ with temperature is approximately $4.0 \% / \mathrm{K}$ in CAMC and NCEPC. About $16 \%$ of the interannual variability in $\mathrm{HNO}_{3}$ can be explained by changes in temperature (Fig. 6). It is possible that changes in precipitation and rainout mask any simple relation between $\mathrm{HNO}_{3}$ and surface temperature.

Carbon monoxide might also be expected to exhibit Clausius-Clapeyron scaling. At steady-state the concentration of $\mathrm{CO}$ is determined primarily by its emissions $(E)$, production $(P)$ from the oxidation of other species and loss through reaction with $\mathrm{OH}$. Assuming that $[\mathrm{OH}]$ and $[\mathrm{CO}]$ are not correlated this gives:

$[\mathrm{CO}]=\frac{E+P}{k_{4}[\mathrm{OH}]}$

Differentiating with respect to temperature and assuming that only $[\mathrm{OH}]$ changes gives:

$\delta[\mathrm{CO}] /[\mathrm{CO}]=-\delta[\mathrm{OH}] /[\mathrm{OH}] \cong-0.07 \delta T$

The response in CAMC $(-2.5 \% / \mathrm{K})$ and NCEPC $(-1.8 \% / \mathrm{K})$ is considerably less than estimated from Clausius-Clapeyron scaling. Note that while the emissions of $\mathrm{CO}$ occur primarily in the middle to high latitudes of the N.H. the largest $\mathrm{OH}$ burden is in the tropics.

The response of lightning $\mathrm{NO}_{\mathrm{x}}$ emissions to climate change is of interest when evaluating the effect of a future climate on atmospheric chemistry. Both the short and long-term simulations using CAM increase lighting NO emissions at a rate larger then implied by Clausius-Clapeyron scaling. On the otherhand in NCEPC there is no significant correlation between temperature change and lightning $\mathrm{NO}_{\mathrm{x}}$ emissions. The lack of correlation in NCEPC may be related to the decoupling between temperature and precipitation in NCEPC (Fig. 6b).

The primary loss of ozone is through the reaction of $\mathrm{O}^{1} \mathrm{D}$ with water vapor (Eq. 1). Therefore one might also expect ozone to exhibit Clausius-Clapeyron scaling. However, the response of ozone to temperature change is small in CAMC $(-1.2 \% / \mathrm{K})$ and not significant in NCEPC. Ozone has a complex response to climate change: a predicted increase in stratospheric-tropospheric exchange in many models is counteracted by increased ozone destruction by water vapor (Stevenson et al., 2006). In addition, over polluted regions most simulations of climate change predict increased ozone concentrations (e.g., Murazaki and Hess, 2006).

\section{Summary}

Hindcasts of chemical variability must inevitably utilize meteorology from meteorological reanalysis or meteorology from a general circulation model, where the latter is preferably constrained by observed SSTs. We analyze the longterm interannual variability in two hindcast simulations using MOZART2 from 1979-1999: one driven by the NCEP reanalysis data (NCEPC), the other driven by winds from a GCM (CAM3) in a historical sea surface temperature simulation (CAMC). No annual changes in emissions were included in these hindcasts so variability can solely be attributed to the meteorology. Differences in the global averages of the analyzed variables in the two simulations are generally less than $5 \%$. The global interannual relative variability in the two simulations ranges from approximately one half percent to a maximum of almost $7.6 \%$ (lightning $\mathrm{NO}_{\mathrm{x}}$ emissions in NCEPC). The interannual variability of some fields is considerably different between the two simulations. Locally, relative interannual variability between 3 and $10 \%$ is common, although relative variability maxima for ozone and $\mathrm{CO}$ reached $20 \%$ during JJA.

In conclusion, the following important points emerge from this study:

1. In an overall sense, the spatial pattern and magnitude of the variability are similar in CAMC and NCEPC. In both simulations the variability of the constituent fields generally has an equatorial maximum and midlatitude or subtropical minimum.

2. Unrealistic changes in the trends of key variables in the NCEP reanalysis prior to 1979 suggests NCEP reanalysis must be treated with caution prior to this time. Between 1979 and 1999 the trends in a number of key variables (temperature, water vapor and cloudiness) in NCEPC do not match the trends in CAMC and are not supported by measurements. The CAMC simulation reproduces the sign of observed trends in temperature, water vapor, precipitation and cloudiness since 1979. Both simulations simulate a positive trend in precipitation. Thus in NCEPC there is a decoupling between the changes in temperature, humidity and cloudiness and those of precipitation. Some of the disadvantages of using NCEP meteorology in long-term simulations must be tempered by its value in the interpretation and forecasts of episodic field campaigns (e.g., Arellano et al., 2007).

3. Global changes in $\mathrm{CO}, \mathrm{OH}, \mathrm{O}_{3}$ and $\mathrm{HNO}_{3}$ show a significant relationship to changes in surface temperature (with exception of ozone in NCEPC), but the response is less than predicted using simple arguments based on Clausius-Clapeyron scaling $(7 \% / \mathrm{K})$. The response of $\mathrm{OH}(6 \% / \mathrm{K})$ is closest to that expected from the scaling arguments, while the response of ozone $(-1.2 \% / \mathrm{K}$ in CAMC) is the furthest. Note that in both the current and future climates lightning $\mathrm{NO}_{\mathrm{x}}$ emissions in CAMC show a strong response to changes in surface temperature (greater than $7 \% / \mathrm{K}$ ). It is evident that feedbacks 
within the climate system modify the response of these species to changes in surface temperature.

4. Except for $\mathrm{OH}$, precipitation and possibly water vapor, we find that the response due to the short-term variability in surface temperature corresponds very closely to longer-term changes over the 21 st century. This suggests that understanding natural variability in the current climate may illuminate future changes.

5. Principal component analysis of global timeseries in CAMC and NCEPC reveals a coupled meteorological and chemical response in the current climate which explains a large fraction of the variability of the examined variables ( $57 \%$ in CAMC, $42 \%$ in NCEPC). This mode highlights the physics whereby increases in surface temperature drive increases in water vapor, precipitation, cloudiness, and lightning $\mathrm{NO}_{\mathrm{x}}$ with concomitant changes in $\mathrm{OH}$ and $\mathrm{CO}$. In CAMC this mode explains most of the global variance in these fields. In NCEPC this mode of variability is similar, although notably, it is associated with variability in ozone, but not with the variability precipitation. Differences in this mode of variability explain many of the key differences between the simulations. In neither simulation is this mode strongly correlated with El Niño.

6. Significant temporal trends in $\mathrm{CO}$ and $\mathrm{OH}$ occur in CAMC. These trends are related to trends in surface temperature through the global mode described above. The NCEPC simulation does not reproduce these changes. Both simulations show significant trends in precipitation and lightning $\mathrm{NO}_{\mathrm{x}}$.

7. SCNEP and CAMC show differing responses to El Niño. In NCEPC (but not in CAMC) the 1st EOF in precipitation is highly correlated with El Niño, in CAMC (but not in NCEPC) the 1st EOF in lightning $\mathrm{NO}_{\mathrm{x}}$ is highly correlated with El Niño. In both the tropics and globally CAMC shows a significant correlation between El Niño and total ozone, while NCEP gives no significant correlation.

8. Ozone variability is very different in the CAMC and NCEPC simulations. As noted above in CAMC ozone variability is largely controlled by El Niño. There is a weak response of ozone to changes in surface temperature in CAMC, both during current conditions, but also when examined over the 21st century. In NCEPC, ozone variations are largely explained by the 1 st mode in the principal mode analysis of the global timeseries, but in such a way that increases in ozone and water vapor are positively correlated. These ozone variations are also not correlated with El Niño. We believe that the correlation between this mode and ozone is likely due to the long-term ozone trend. Ozone variations are not correlated between the NCEPC and CAMC simulations, suggesting that SST does not play a large role in simultaneously forcing these variations.

The following recommendations and suggestions for further study emerge from this study:

1) Reanalysis data must be used with great care in chemical simulations. In some cases climate models may do better in capturing chemical and meteorological trends.

2) The response of chemistry model to El Niño show considerable discrepancy between this study and that of Doherty et al. (2006). These results and those of Doherty et al. (2006) show a range of different chemical responses to El Niño. These range from very weak in NCEPC to the large global response reported in the STOCHEM model. The differences in this response are not well understood. Due to the importance of El Niño in the atmosphere system, additional hindcast simulations are necessary to better understand the chemical response to El Niño.

3 ) Is the response of atmospheric composition (independent of changes in emissions) to climate change robust across a wide variety of models? The relationships between surface temperature change and chemical changes obtained here for a number of variables are worth exploring in simulations in other models, both during present day conditions, but also in simulations of future climate. For some variables the response differs considerably between CAMC and NCEPC. These relationships appear to present a succinct test of the response of the chemical system to meteorological variability and change. To the extent these relationships do not follow the Clausius-Clapeyron scaling, they are a measure of the internal feedbacks within the model simulation.

Acknowledgements. Most of this work was performed at NCAR which is operated by the University Corporation for Atmospheric Research under sponsorship of the National Science Foundation.

Edited by: R. Vautard

\section{References}

Abbot, D. S., Palmer, P. I., Martin, R. V., Chance, K. V., Jacob, D. J., and Guenther, A.: Seasonal and interannual variability of North American isoprene emissions as determined by formaldehyde column measurements from space, Geophys. Res. Lett., 30(17), 1886, doi:10.1029/2003GL017336, 2003.

Allen, D. J., Kasibhatla, P., Thompson, A. M., Rood, R. B., Doddridge, B. G., Pickering, K. E., Hudson, R. D., and Lin, S.: Transport-induced interannual variability of carbon monoxide determined using a chemistry and transport model, J. Geophys. Res., 101, 28655-28669, 1996.

Andersson, C., Langner, J., and Bergstrom, R.: Tellus, 59B, 77-98, 2007.

Arellano, Jr., A. F., Raeder, K., Anderson, J. L., Hess, P. G., Emmons, L. K., Edwards, D. P., Pfister, G. G., Campos, T. L., and Sachse, G. W.: Evaluating model performance of an ensemblebased chemical data assimilation system during INTEX-B field 
mission, Atmos. Chem. Phys., 7, 5695-5710, 2007,

http://www.atmos-chem-phys.net/7/5695/2007/.

Bengtsson, L., Hodges, K. I., and Hagemann, S.: Sensitivity of large-scale atmospheric analyses to humidity observations and its impact on the global water cycle and tropical and extratropical weather systems in ERA40, Tellus A, 56(3), 202-217, doi:10.1111/j.1600-0870.2004.00053.x, 2004.

Bousquet, P., Ciais, P., Miller, J. B., et al.: Contribution of anthropogenic and natural sources to atmospheric methane variability, Nature, 443(7110), 439-443, doi:10.1038/nature05132, 2006.

Bousquet, P., Hauglustaine, D. A., Peylin, P., Carouge, C., and Ciais, P.: Two decades of $\mathrm{OH}$ variability as inferred by an inversion of atmospheric transport and chemistry of methyl chloroform, Atmos. Chem. Phys., 5, 2635-2656, 2005,

http://www.atmos-chem-phys.net/5/2635/2005/.

Bowman, K. P. and Erukhimova, T.: Comparison of Global-Scale Lagrangian Transport Properties of the NCEP Reanalysis and CCM3, J. Climate, 17, 1135-1146, 2004.

Cess, R. D., Potter, G. L., Blanchet, J. P., et al.: Intercomparison and interpretation of climate feedback processes in 19 atmospheric general circulation models, J. Geophys. Res., 95, 16601-16615, 1990.

Chang, J. S.: Three-dimensional Eulerian acid deposition model: physical concepts and formulation, J. Geophys. Res., 92, 1468114700, 1987.

Chen, Y. H. and Prinn, R. G.: Atmospheric modeling of highand low-frequency methane observations: importance of interannually varying transport, J. Geophys. Res., 110(27), D10303, doi:doi:10.1029/2004JD005542, 2005.

Collins, W. D., Blackmon, M. L., Bonan, G. B., et al.: The Community Climate System Model Version 3 (CCSM3), J. Climate, 19, 2122-2143, 2006.

Creilson, J. K., Fishman, J., and Wozniak, A. E.: Intercontinental transport of tropospheric ozone: a study of its seasonal variability across the North Atlantic utilizing tropospheric ozone residuals and its relationship to the North Atlantic Oscillation, Atmos. Chem. Phys., 3, 2053-2066, 2003,

http://www.atmos-chem-phys.net/3/2053/2003/.

Creilson, J. K., Fishman, J., and Wozniak, A. E.: Arctic Oscillationinduced variability in satellite-derived tropospheric ozone, Geophys. Res. Lett., 32(14), L14822, doi:10.1029/2005GL023016, 2005.

Dai, A., Karl, T. R., Sun, B., and Trenberth, K. E.: Recent trends in cloudiness over the United States: a tale of monitoring inadequacies, B. Am. Meteor. Soc., 87(5), 597-606, doi:10.1175/BAMS87-5-597, 2006.

Dentener, F., Peters, W., Krol, M., Van Weele, M., Bergamaschi, P., and Lelieveld, J.: Interannual variability and trend of $\mathrm{CH}_{4}$ lifetime as a measure for $\mathrm{OH}$ changes in the 1979-1993 time period, J. Geophys. Res., 108(D15), 4442, doi:10.1029/2002JD002916, 2003.

Doherty, R. M., Stevenson, D. S., Johnson, C. E., Collins, W. J., and Sanderson, M. G.: Tropospheric ozone and el Niño-Southern Oscillation: Influence of atmospheric dynamics, biomass burning emissions, and future climate change, J. Geophys. Res. (D. Atmos.), 111(D19), D19304, doi:10.1029/2005JD006849, 2006.

Eckhardt, S., Stohl, A., Beirle, S., Spichtinger, N., James, P., Forster, C., Junker, C., Wagner, T., Platt, U., and Jennings, S. G.: The North Atlantic oscillation controls air pollution transport to the Arctic, Atmos. Chem. Phys., 3, 1769-1778, 2003, http://www.atmos-chem-phys.net/3/1769/2003/.

Edwards, D. P. et al.: Observations of carbon monoxide and aerosols from the Terra satellite: Northern Hemisphere variability, J. Geophys. Res., 109(D24), doi:10.1029/2004JD004727, 2004.

Emmons, L. K., Hess, P., Klonecki, A., et al.: Budget of tropospheric ozone during TOPSE from two chemical transport models, J. Geophys. Res., 108(D8), 8372, doi:10.1029/2002JD002665, 2003.

Fischer, P. H., Brunekreef, B., and Lebret, E.: Air pollution related deaths during the 2003 heat wave in the Netherlands, Atmos. Environ., 38, 1083-1085, 2004.

Giorgi, F. and Chameides, W. L.: Rainout parameterization in a photochemical model, J. Geophys. Res., 90(D5), 7872-7880, 1985.

Guenther, A., Hewitt, C. N., Erickson, D., et al.: A global model of natural volatile organic compound emissions, J. Geophys. Res., 100, 8873-8892, 1995.

Hack, J. J., Caron, J. M., Yeager, S. G., Oleson, K. W., Holland, M. M., Truesdale, J. E., and Rasch, P. J.: Simulation of the global hydrological cycle in the CCSM community atmosphere model version 3 (CAM3): mean features, J. Climate, 19, 2199_ 2221, 2006.

Hack, J. J.: Parameterization of moist convection in the National Center for Atmospheric Research community climate model (CCM2), J. Geophys. Res., 99, 5551-5568, 1994.

Hartley, D. E. and Black, R. X.: Mechanistic analysis of interhemispheric transport, Geophys. Res. Lett., 22(21), 2945-2948, 1995.

Held, I. M. and Soden, B. J.: Robust responses of the hydrological cycle to global warming, J. Climate, 19, 5686-5699, 2006.

Hess, P. G. and Lamarque, J.: Ozone source attribution and its modulation by the Arctic oscillation during the spring months, J. Geophys. Res., 112(D11), D11303, doi:10.1029/2006JD007557, 2007.

Holtslag, A. A. M. and Boville, B. A.: Local versus nonlocal boundary-layer diffusion in a global climate model, J. Climate, 6, 1825-1842, 1993.

Horowitz, L. W., Walters, S., Mauzerallet, D. L., et al.: A global simulation of tropospheric ozone and related tracers: Description and evaluation of MOZART, version 2, J. Geophys. Res., 108(D24), 4784, doi:10.1029/2002JD002853, 2003.

Hurrell, J. W.: Decadal Trends in the North Atlantic Oscillation: Regional Temperatures and Precipitation, Science, 269(5224), 676-679, 1995.

Jaffe, D. and Ray, J.: Increase in surface ozone at rural sites in the western US, Atmos. Environ., 41(26), 5452-5463, 2007.

Kallberg, P., Berrisford, P., Hoskins, B., Simmons, A., Uppala, S., Lamy-Thepaut, S., and Hine, R.: ERA-40 Atlas, 1-191, 2005.

Kalnay, E., Kanamitsu, M., Kistler, R., et al.: The NCEP/NCAR 40year reanalysis project, B. Am. Meteorol. Soc., 77(3), 437-471, 1996.

Karlsdóttir, S. and Isaksen, I. S. A.: Changing methane lifetime: Possible cause for reduced growth, Geophys. Res. Lett., 27(1), 93-96, 2000.

Kistler, R., Kalnay, E., Collins, W., Saha, S., White, G., Woollen, J., Chelliah, M., Ebisuzaki, W., Kanamitsu, M., and Kousky, V.: The NCEP-NCAR 50-year reanalysis: monthly means cd-rom and documentation, B. Am. Meteorol. Soc., 82(2), 247-267, 2001. 
Krol, M. and Lelieveld, J.: Can the variability in tropospheric $\mathrm{OH}$ be deduced from measurements of 1,1,1-trichloroethane (methyl chloroform)? J. Geophys. Res., 108(D3), 4125, doi:10.1029/2002JD002423, 2003.

Labrador, L. J., Von Kuhlmann, R., and Lawrence, M. G.: Strong sensitivity of the global mean $\mathrm{OH}$ concentration and the tropospheric oxidizing efficiency to the source of $\mathrm{NO}_{\mathrm{x}}$ from lightning, Geophys. Res. Lett., 31(6), L06102, doi:10.1029/2003GL019229, 2004.

Lamarque, J. and Hess, P. G.: Arctic Oscillation modulation of the Northern Hemisphere spring tropospheric ozone, Geophys. Res. Lett., 31(6), L06127, doi:10.1029/2003GL019116, 2004.

Mahowald, N. M., Zender, C. S., Luo, C., Savoie, D., Torres, O., and del Corral, J.: Understanding the 30-year Barbados desert dust record, J. Geophys. Res., 107(D21), 4561, doi:10.1029/2002JD002097, 2002.

Mahowald, N. M., Rasch, P. J., Eaton, B. E., Whittlestone, S., and Prinn, R. G.: Transport of super(2) super(2) super(2)radon to the remote troposphere using the Model of Atmospheric Transport and Chemistry and assimilated winds from ECMWF and the National Center for Environmental Prediction/NCAR, J. Geophys. Res., 102, 28139-28151, 1997.

Murazaki, K. and Hess, P.: How does climate change contribute to surface ozone change over the United States?, J. Geophys. Res., 111(D5), D05301, doi:10.1029/2005JD005873, 2006.

Nevison, C. D., Mahowald, N. M., Weiss, R. F., and Prinn, R. G.: Interannual and seasonal variability in atmospheric $\mathrm{N}_{2} \mathrm{O}$, Global Biogeochem. Cy., 21(3), GB3017, doi:10.1029/2006GB002755, 2007.

Norris, J. R.: On trends and possible artifacts in global ocean cloud cover between 1952 and 1995, J. Climate, 12(6), 1864-1870, 1999.

Olivier, J., Peters, J., Granier, C., Petron, G., Muller, J. F., and Wallens, S.: Present and future surface emissions of atmospheric compounds, POET Rep. 2, EU Proj. EVK2-1999-00011, 1999.

Oltmans, S. J., Lefohn, A. S., Harris, J. M., et al.: Long-term changes in tropospheric ozone, Atmos. Environ., 40, 3156-3173, 2006.

Ordonez, C., Brunner, D., Staehelin, J., Hadjinicolaou, P., Pyle, J. A., Jonas, M., Wernli, H., and Prevot, A. S. H.: Strong influence of lowermost stratospheric ozone on lower tropospheric background ozone changes over Europe, Geophys. Res. Lett., 34(7), L07805, doi:10.1029/2006GL029113, 2007.

Peters, W., Krol, M., Dentener, F., and Lelieveld, J.: Identification of an El Niño-Southern Oscillation signal in a multiyear global simulation of tropospheric ozone, J. Geophys. Res., 106(D10), 10389-10402, 2001.

Pickering, K. E., Wang, Y., Tao, W., Price, C., and Mueller, J.: Vertical distributions of lightning $\mathrm{NO}_{\mathrm{x}}$ for use in regional and global chemical transport models, J. Geophys. Res., 103, 31203-31216, 1998.

Prather, M., Ehhalt, D., Dentener, F., Derwent, R. G., Dlugokencky, E., Holland, E., Isaksen, I. S. A., Katima, J., Kirchhoff, V., Matson, P., Midgley, P. M., and Wang, M.: Climate Change 2001: The Scientific Basis, Atmospheric Chemistry and Greenhouse Gases, Chap. 4, Cambridge Univ. Press, New York, USA, 239287, 2001.

Price, C., Penner, J., and Prather, M.: $\mathrm{NO}_{\mathrm{x}}$ from lightning. Part 1: Global distribution based on lightning physics, J. Geophys. Res.,
102, 5929-5941, 1997.

Prinn, R. G., Huang, J., and R. F. Weiss: Evidence for variability of atmospheric hydroxyl radicals over the past quarter century, Geophys. Res. Lett., 32(7), L07809, doi:10.1029/2004GL022228, 2005.

Prinn, R. G., Huang, J., Weiss, R. F., et al.: Evidence for Substantial Variations of Atmospheric Hydroxyl Radicals in the Past Two Decades, Science, 292, 1882-1888, 2001.

Rasch, P. J., Mahowald, N. M., and Eaton, B. E.: Representations of transport, convection, and the hydrologic cycle in chemical transport models: implications for the modeling of short-lived and soluble species, J. Geophys. Res., 102, 28127-28138, 1997.

Ross, R. J. and Elliott, W. P.: Radiosonde-based Northern Hemisphere tropospheric water vapor trends, J. Climate, 14(13), 1602-1611, 2001.

Simmonds, P. G., Derwent, R. G., Manning, A. L., and Spain, G.: Significant growth in surface ozone at Mace Head, Ireland, 1987-2003, Atmos. Environ., 38, 4769-4778, 2004.

Slingo, A., Pamment, J. A., Allan, R. P., and Wilson, P. S.: Water vapor feedbacks in the ECMWF reanalyses and Hadley Centre climate model, J. Climate, 13(17), 3080-3098, 2000.

Soden, B. J.: The sensitivity of the tropical hydrological cycle to ENSO, J. Climate, 13(3), 538-549, 2000.

Stevenson, D. S., Dentener, F. J., Schultz, M. G., et al.: Multimodel ensemble simulations of present-day and near-future tropospheric ozone, J. Geophys. Res. Atmos., 111(D8), D08301, doi:10.1029/2005JD006338, 2006.

Sudo, K. and Takahashi, M.: Simulation of tropospheric ozone changes during 1997-1998 El Niño: Meteorological impact on tropospheric photochemistry, Geophys. Res. Lett., 28(21), 40914094, 2001.

Tie, X., Emmons, L., and Horowitz, L.: Effect of sulfate aerosol on tropospheric $\mathrm{NO}_{\mathrm{x}}$ and ozone budgets: Model simulations and TOPSE evidence, J. Geophys. Res., 108(D4), 8364, doi:10.1029/2001JD001508, 2003.

Trenberth, K. E. and Stepaniak, D. P.: Indices of El Niño Evolution, J. Clim., 14(8), 1697-1701, 2001.

Trenberth, K. E., Fasullo, J., and Smith, L.: Trends and variability in column-integrated atmospheric water vapor, Clim. Dynam., 24, 741-758, 2005.

Uppala, S. M. et al.: The ERA-40 re-analysis, Q. J. Roy. Meteor. Soc., 131, 2961-3012, 2005.

Vukovich, F. M.: Time scales of surface ozone variations in the regional, non-urban environment, Atmos. Environ., 31, 15131530, 1997.

Wang, J. S., Logan, J. A., McElroy, M. B., Duncan, B. N., Megretskaia, I. A., and Yantosca, R. M.: A 3-D model analysis of the slowdown and interannual variability in the methane growth rate from 1988 to 1997, Global Biogeochem. Cy., 18(3), GB3011, doi:10.1029/2003GB002180, 2004.

Warwick, N. J., Bekki, S., Law, K. S., Nisbet, E. G., and Pyle, J. A.: The impact of meteorology on the interannual growth rate of atmospheric methane, Geophys. Res. Lett., 29(20), 1947, doi:10.1029/2002GL015282, 2002.

Wentz, F. J., Ricciardulli, L., Hilburn, K., and Mears, C.: How Much More Rain Will Global Warming Bring? Science, 317(5835), 233-235, doi:10.1126/sience.1140746, 2007.

Wilks, D.: Statistical Methods in the Atmospheric Sciences, vol. 91, Academic Press, Inc., 525 B St. Ste. 1900 San Diego CA 92101- 
4495 USA, [http://www.academicpress.com], 648 pp., 2006.

Zbinden, R. M., Cammas, J.-P., Thouret, V., Nédélec, P., Karcher, F., and Simon, P.: Mid-latitude tropospheric ozone columns from the MOZAIC program: climatology and interannual variability Atmos. Chem. Phys., 6, 1053-1073, 2006, http://www.atmos-chem-phys.net/6/1053/2006/.

Zhang, G. J. and McFarlane, N. A.: Sensitivity of climate simulations to the parameterization of cumulus convection in the Canadian Climate Centre General Circulation Model, AtmosphereOcean, Ontario, Canada, 33, 407-446, 1995.
Zhou, W. and Sanso, B.: Statistical inference for atmospheric transport models using process convolutions, Environmetrics, 19(1), 87-101, 2008.

Ziemke, J. R. and Chandra, S.: Seasonal and interannual variabilities in tropical tropospheric ozone, J. Geophys. Res., 104(D17), 21425-21442, 1999.

Ziemke, J. R. and Chandra, S.: La Nina and El Niñoinduced variabilities of ozone in the tropical lower atmosphere during 1970-2001, Geophys. Res. Lett., 30(3), 1142, doi:10.1029/2002GL016387, 2003. 